\title{
ADRIANO ANDRADE DE SOUZA
}

\section{Proteção Estatal Suficiente do Meio Ambiente por meio da Responsabilidade Civil}

\begin{abstract}
Tese apresentada à Banca Examinadora do Programa de Pós-Graduação em Direito da Faculdade de Direito da Universidade de São Paulo, na área de concentração Direito Civil, sob a orientação da Professora Associada Dra. Patrícia Faga Iglecias Lemos.
\end{abstract}

UNIVERSIDADE DE SÃO PAULO

FACULDADE DE DIREITO

São Paulo - SP 
|Catalogação da Publicação

Serviço de Biblioteca e Documentação

Faculdade de Direito da Universidade de São Paulo

Souza, Adriano Andrade de

Protecão Estatal Suficiente do Meio Ambiente por meio da Responsabilidade Civil ; Adriano Andrade de Souza ; orientadora Patrícia Faga Iglecias Lemos -Săo Paulo, 2020.

451

Tese (Doutorado - Programa de Pós-Graduação em Direito Civil) - Faculdade de Direito, Universidade de Sẵo Paulo, 2020.

1. Responsabilidade Civil. 2. Meio Ambiente. 3. Direito Fundamental. 4. Proibição de Insuficiência. 5. Dever Estatal de Proteção. I. Lemos, Patricia Faga Iglecias, orient. II. Titulo. 
Nome: SOUZA, Adriano Andrade de

Título: Proteção Estatal Suficiente do Meio Ambiente por meio da Responsabilidade Civil

Tese apresentada à Faculdade de Direito da Universidade de São Paulo para obtenção do título de Doutor em Direito.

Aprovado em:

\section{Banca Examinadora}

$\operatorname{Prof}(\mathrm{a}) . \operatorname{Dr}(\mathrm{a})$.

Instituição:

Julgamento:

$\operatorname{Prof}(\mathrm{a}) . \operatorname{Dr}(\mathrm{a})$.

Instituição:

Julgamento:

Prof(a). Dr(a).

Instituição:

Julgamento:

Prof(a). Dr(a).

Instituição:

Julgamento:

Prof(a). Dr(a).

Instituição:

Julgamento: 

À minha esposa, com amor e gratidão por sua compreensão, carinho, e incansável apoio ao longo do período de elaboração deste trabalho. Aos meus filhos, pelos momentos de sua tenra infância que de meu convívio privei. 



\section{AGRADECIMENTOS}

À Prof. Dra. Patrícia Iglecias, pela atenção e apoio durante o processo de orientação.

Aos Profs. Drs. Ingo Sarlet e Jens Kersten, por me possibilitarem o acesso às bibliotecas da Ludwig-Maximilians-Universität, em Munique.

Ao querido amigo Prof. Dr. Thiago Fensterseifer, por haver gentilmente me acompanhado em Munique.

A Vagner, Sydilene, Claudia e Junia e todos os demais servidores da biblioteca do Ministério Público de São Paulo, que sempre me atenderam muito solicitamente. 



\section{RESUMO}

SOUZA, Adriano Andrade de. Proteção Estatal Suficiente do Meio Ambiente por meio da Responsabilidade Civil. 451 p. Tese (Doutorado) - Faculdade de Direito Universidade de São Paulo, São Paulo, 2020.

A responsabilidade civil por danos ambientais é um instrumento essencial para que o dever de proteção do meio ambiente, insculpido no caput do art. 225 da Constituição Federal, seja efetivamente realizado. Assim como se dá com outras matérias disciplinadas pela Lei Fundamental, algumas das normas constitucionais que dão suporte à responsabilidade civil têm baixa densidade normativa, e seus comandos são prima facie. $\mathrm{O}$ descumprimento de deveres constitucionais prima facie por atos normativos infraconstitucionais demanda um controle de proporcionalidade para o qual o tradicional controle da proibição do excesso não é estruturalmente adequado. Para essa tarefa, doutrina e jurisprudência alemãs, e, num segundo momento, portuguesas, identificaram uma nova figura dogmática, a proibição da insuficiência, e para ela elaboraram metodologias específicas. Considerando que a literatura e jurisprudência sobre o tema no Brasil ainda é incipiente, o propósito deste trabalho foi o de investigar os contributos acadêmicos e jurisprudenciais estrangeiros, e, na medida de sua disponibilidade, os nacionais, a fim de verificar a viabilidade da aplicação da proibição de insuficiência sob a ordem jurídica nacional. Uma vez constatada tal possibilidade, estruturou-se um método voltado ao controle da insuficiência de atos normativos à luz dos parâmetros disponíveis em nossa Constituição, sobretudo aqueles relacionados à responsabilidade civil ambiental por danos ambientais.

Palavras-chave: responsabilidade civil. meio ambiente. direito fundamental. proibição de insuficiência. dever estatal de ação. dever estatal de proteção. 



\begin{abstract}
SOUZA, Adriano Andrade de. Enough State Protection of the Environment through Civil Liability. 451 p. PhDThesis (Doctorate) - Faculty of Law - University of São Paulo, São Paulo, 2020.

The civil liability for environmental damage is an essential instrument for the duty to protect the environment, inscribed in the caput of art. 225 of the Federal Constitution. As with other matters governed by the Basic Law, some of the constitutional rules that support civil liability have low normative density, and their commands are prima facie. The non-fulfillment of constitutional duties prima facie by infra-constitutional normative acts demands a proportionality control for which the traditional balancing is not structurally adequate. For this task, German and, in a second moment, Portuguese doctrine and jurisprudence have identified a new dogmatic figure, the prohibition of insufficiency, and for it they have developed specific methodologies. Considering that the literature and jurisprudence on the subject in Brazil is still incipient, the purpose of this work was to investigate foreign academic and case-law contributions, and, to the extent of their availability, the national ones, in order to verify the feasibility of applying the prohibition of insufficiency under the national legal system. Once this possibility was verified, a method was structured to control the insufficiency of normative acts in light of the parameters available in our constitution, especially those related to environmental civil liability for environmental damages.
\end{abstract}

Keywords: civil liability. environment. fundamental right. prohibition of insufficiency. state duty of action. state duty of protection. 



\section{ZUSAMMENFASSUNG}

SOUZA, Adriano Andrade de. Ausreichender staatlicher Schutz der Umwelt durch zivile Verantwortung. 451 S. Dissertation (Doktorat) - Rechtswissenschaftliche Fakultät - Universität São Paulo, São Paulo, 2020.

Die zivilrechtliche Haftung für Umweltschäden ist ein wesentliches Instrument für die in Art. 225 der Bundesverfassung verankerte Pflicht zum Schutz der Umwelt. Wie bei anderen im Grundgesetz geregelten Themen haben einige der verfassungsrechtlichen Regelungen, die die zivilrechtliche Haftung unterstützen, eine geringe normative Dichte, und ihre Gebote sind prima facie. Die Nichterfüllung verfassungsrechtlicher Pflichten durch einfachgesetzliche Normativakte erfordert prima facie eine Verhältnismäßigkeitskontrolle, für die die traditionelle Kontrolle des Übermaßverbots strukturell nicht ausreicht. Für diese Aufgabe haben die deutsche und, in einem zweiten Moment, die portugiesische Lehre und Rechtsprechung eine neue dogmatische Figur, das Untermaßverbot, identifiziert und dafür spezifische Methoden entwickelt. In Anbetracht der Tatsache, dass die Literatur und die Rechtsprechung zu diesem Thema in Brasilien noch in den Anfängen steckt, war der Zweck dieser Arbeit, ausländische akademische und rechtswissenschaftliche Beiträge und, soweit verfügbar, die nationalen Beiträge zu untersuchen, um die Durchführbarkeit der Anwendung des Untermaßverbots im nationalen Rechtssystem zu überprüfen. Nach der Überprüfung dieser Möglichkeit wurde eine Methode zur Kontrolle der Defizite der Normativakte unter Berücksichtigung der in unserer Verfassung vorhandenen Parameter, insbesondere derjenigen, die sich auf die zivilrechtliche Haftung für Umweltschäden beziehen, strukturiert.

Stichworte: Zivilrechtliche Haftung. Umwelt. Grundrecht. Untermaßerbot. staatliche Handlungspflicht. staatliche Schutzpflicht. 



\section{ABREVIATURAS}

ac.

ADCT/CF

ADI

ADIO

ADPF

BVerfG

BVerfGE

BVerfGG

CDC

CF

div.

e.s.e.

LPNMA

NJW

n.r.

n.m.

ob. cit.

pos.

STF

TC

TCF acórdão

Ato das Disposições Constitucionais Transitórias da Constituição da República Federativa do Brasil

Ação Direta de Inconstitucionalidade

Ação Direta de Inconstitucionalidade por Omissão

Arguição de Descumprimento de Preceito Fundamental

Bundesverfassungsgericht (Tribunal Constitucional Federal)

Bundesverfassungsgericht-Entscheidungen (Repositório Oficial de Decisões do Tribunal Constitucional Federal)

Bundesverfassungsgerichtsgesetz (Lei do Tribunal Constitucional Federal)

Código de Defesa do Consumidor (Lei n. 8.078/1990)

Constituição da República Federativa do Brasil

divulgado

em sentido estrito

Lei da Política Nacional do Meio Ambiente (Lei n. 6.938/1981)

Neue Juristische Wochenschrift

nota de rodapé

nota de margem

obra citada

posição

Supremo Tribunal Federal

Tribunal Constitucional (de Portugal)

Tribunal Constitucional Federal (da Alemanha) 



\section{SUMÁRIO}

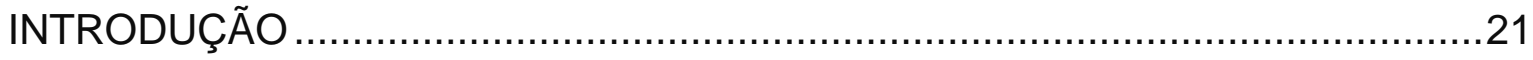

1 MEIO AMBIENTE E FUNDAMENTALIDADE JURÍDICA .......................25

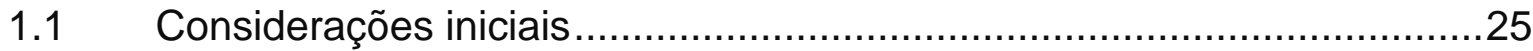

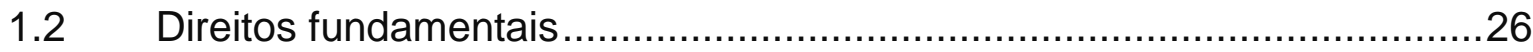

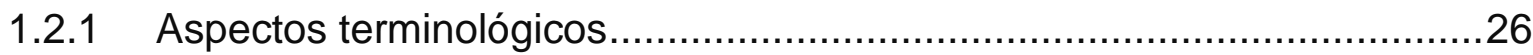

1.1.2 Breve incursão no pensamento subjacente aos direitos fundamentais ....36

1.1.3 Construção histórica dos direitos fundamentais .....................................40

1.1.4 Debate sobre as gerações ou dimensões de direitos ...............................46

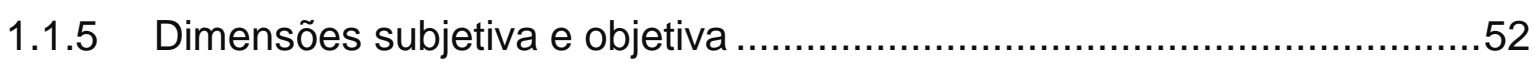

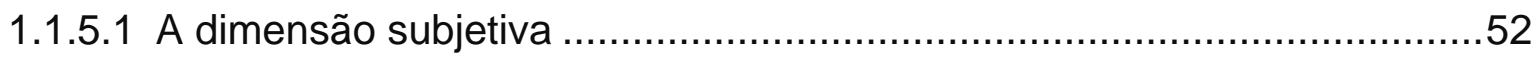

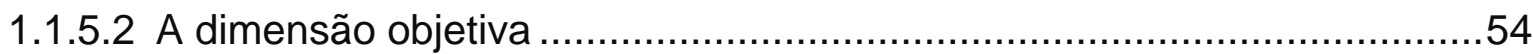

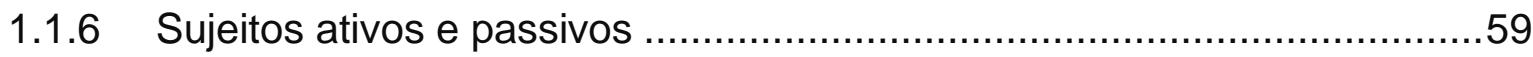

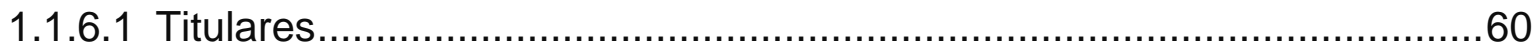

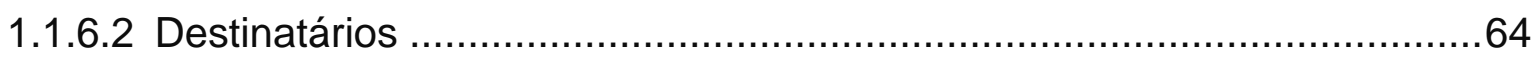

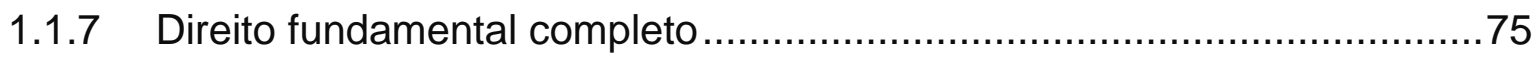

1.1.8 Valorização dos direitos fundamentais na Constituição atual....................77

1.1.9 Concepção materialmente aberta de direitos fundamentais na Constituição atual 78

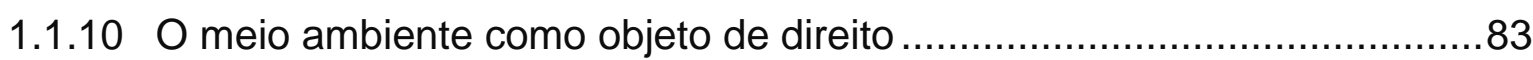

1.1.10.1 O direito humano a um ambiente equilibrado ......................................83

1.1.10.2 O direito fundamental a um ambiente equilibrado ...............................87

1.1.10.3 O direito ao ambiente como direito fundamental completo ...................88

1.1.10.4 O direito ao ambiente como cláusula pétrea........................................90

1.1.10.5 Detalhando o objeto do direito fundamental ambiental........................92

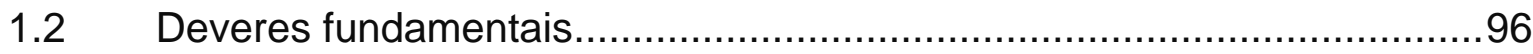

1.2.2 Deveres fundamentais correlatos explícitos ...........................................99

1.2.3 Deveres fundamentais correlatos implícitos ...........................................99

1.2.4 Deveres fundamentais autônomos ........................................................100

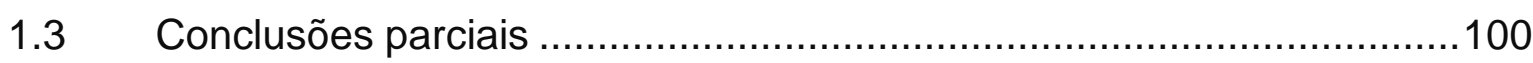

2 RESPONSABILIDADE CIVIL AMBIENTAL ........................................103

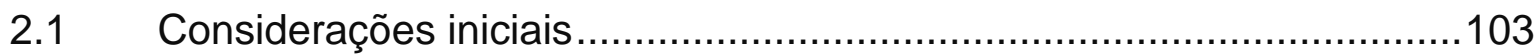

2.2 Dever de proteção e responsabilidade civil ambiental............................103

2.1.1 Efeitos preventivos da função reparatória …….......................................104

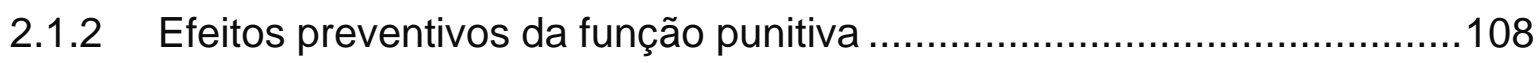

2.1.3 Prevenção como proteção primária.......................................................115 


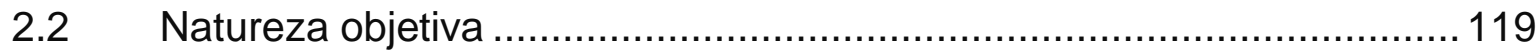

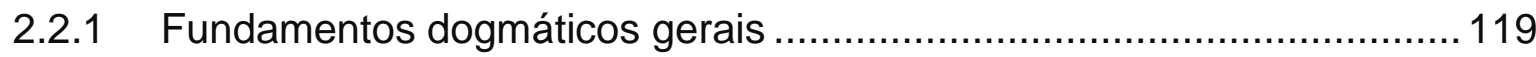

2.2.2 Responsabilidade civil das pessoas jurídicas de direito público ............126

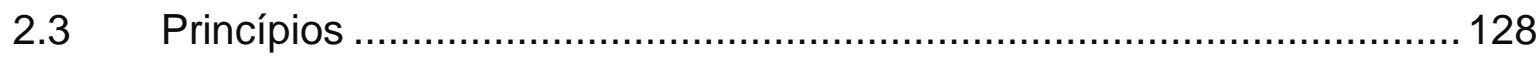

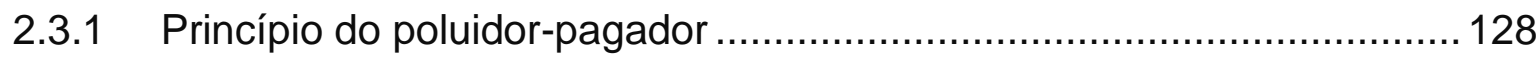

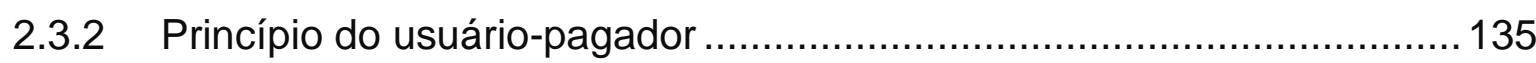

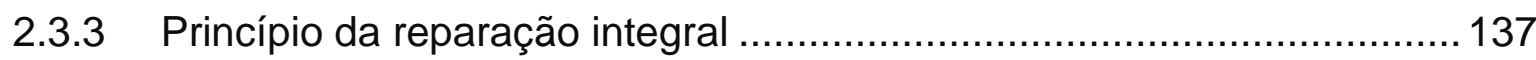

2.3.4 Princípios da prevenção e da precaução …………….......................... 138

2.3.5 Princípio da função socioambiental da propriedade e da posse ............ 145

2.3.5.1 Função socioambiental da propriedade e deveres propter rem .............. 150

2.3.6 Princípio da equidade, responsabilidade ou solidariedade intergeracional 160

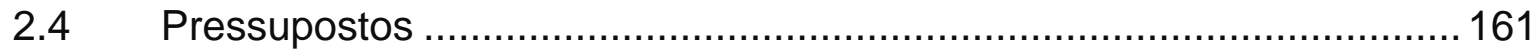

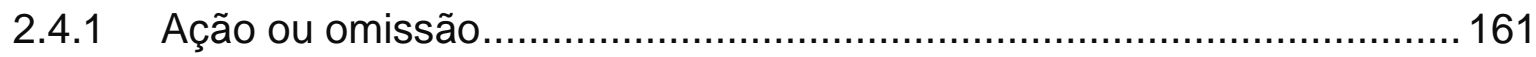

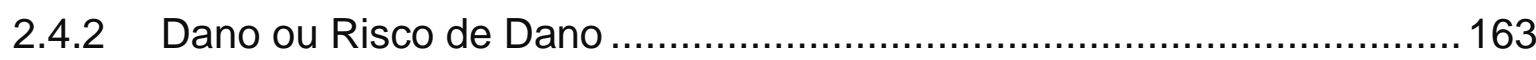

2.4.3 Nexo causal ou condicionalidade adequada ........................................ 174

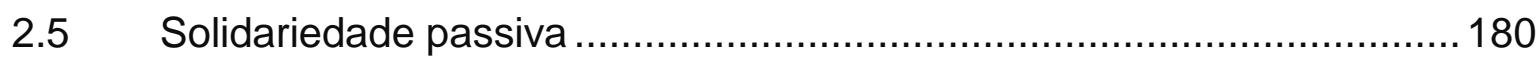

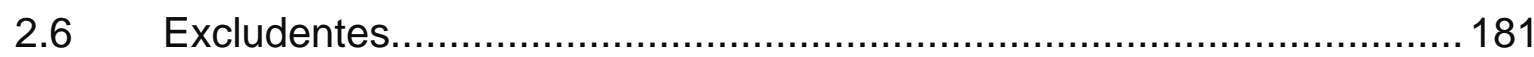

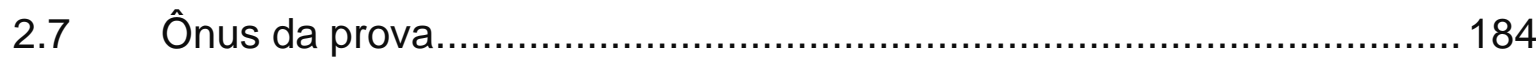

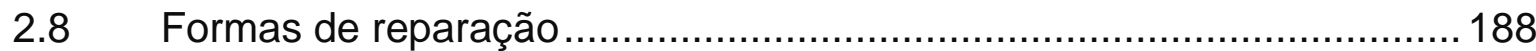

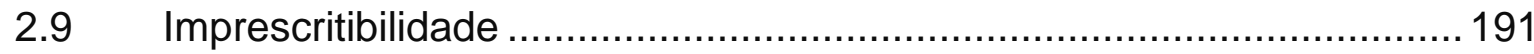

3 PANORAMA GERAL DA PROIBIÇÃO DE INSUFICIÊNCIA..................195

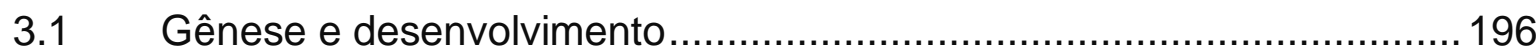

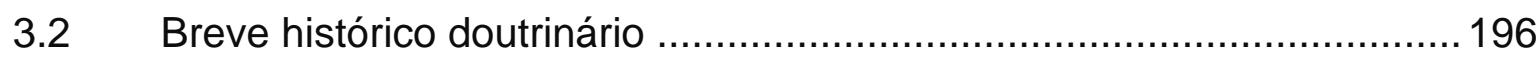

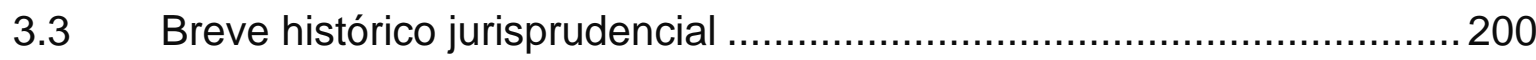

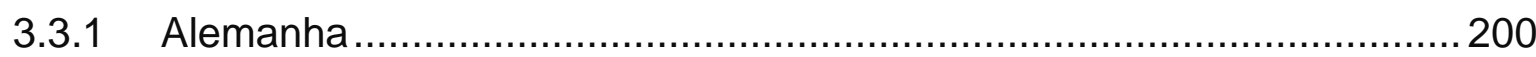

3.3.1.1 Primeira decisão sobre o aborto (Schwangerschaftsabbruch I) .............200

3.3.1.2 Segunda decisão sobre o aborto (Schwangerschaftsabbruch II) ............202

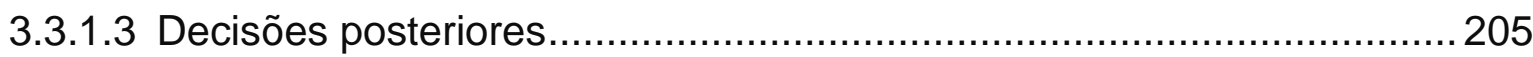

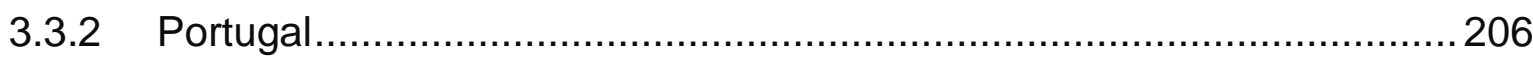

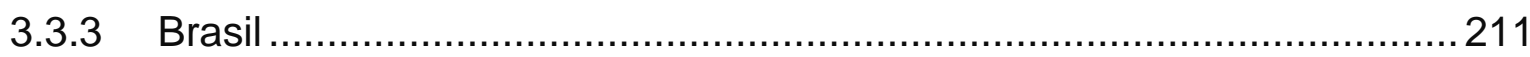

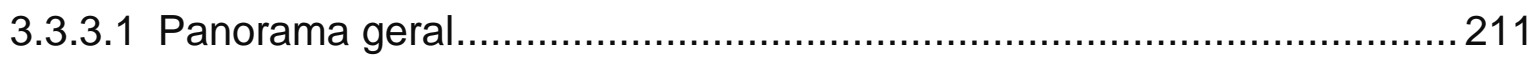

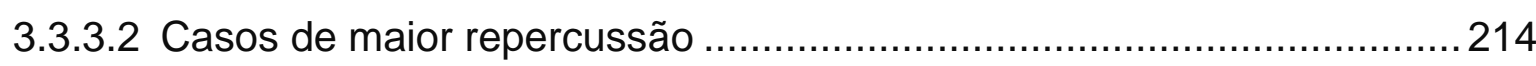

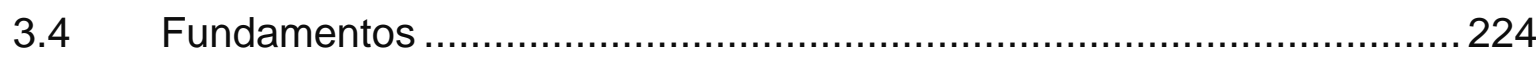

3.4.1 Fundamentação originária: deveres estatais de proteção......................224

3.4.1.1 Deveres explícitos na Constituição ..................................................226

3.4.1.2 Deveres não explícitos no texto constitucional.....................................228 


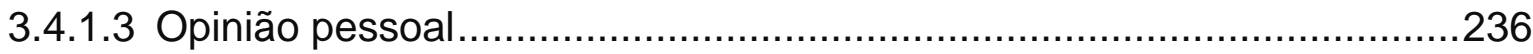

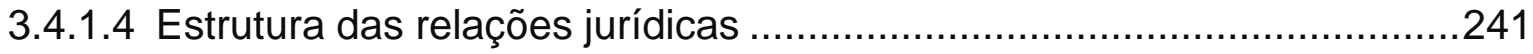

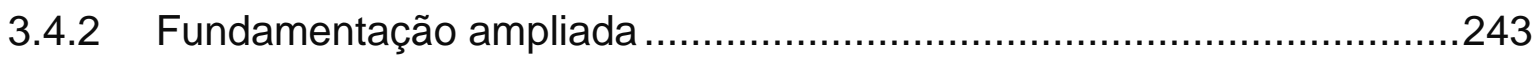

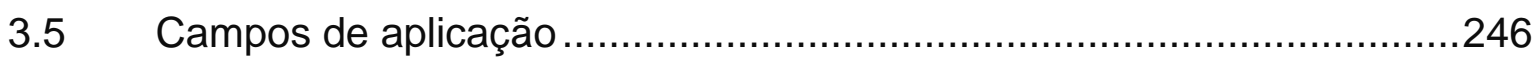

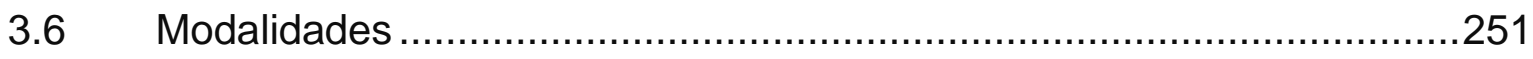

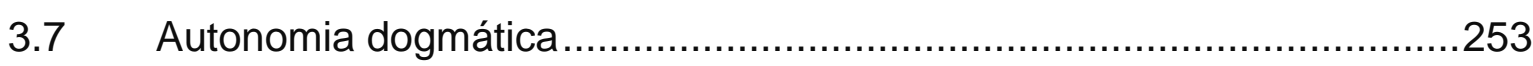

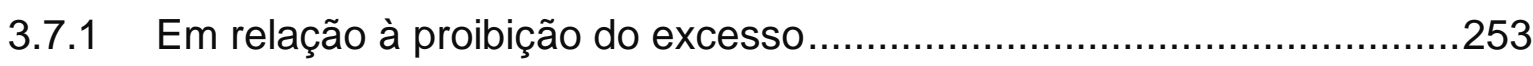

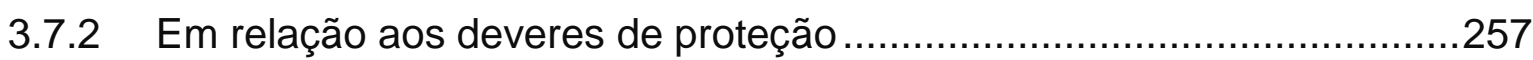

3.7.3 Em relação ao conteúdo essencial dos direitos fundamentais ...............259

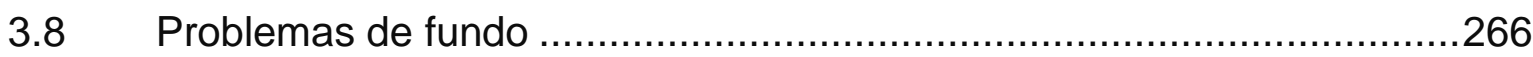

3.8.1 Redução da margem de discricionariedade legislativa...........................266

3.8.2 Prejuízo à orientação liberal dos direitos fundamentais .........................273

3.8.3 Soluções aventadas na doutrina e/ou na jurisprudência .........................274

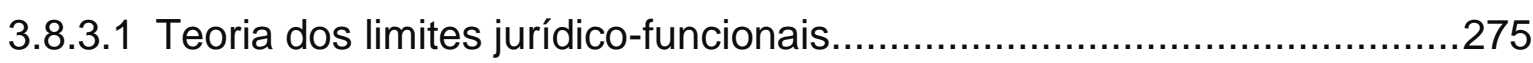

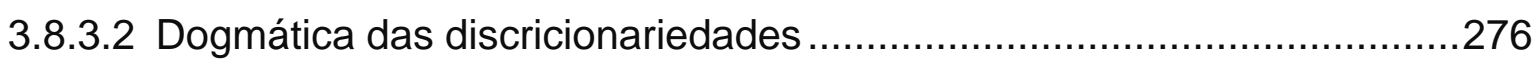

3.8.3.3 Distinção entre normas de ação e normas de controle ..........................278

3.8.3.4 Assimetria entre proibição de insuficiência e do excesso........................280

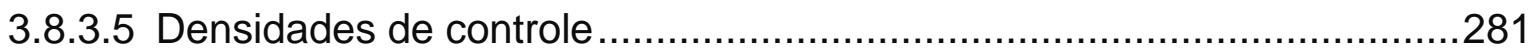

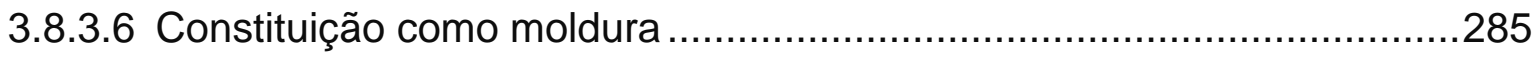

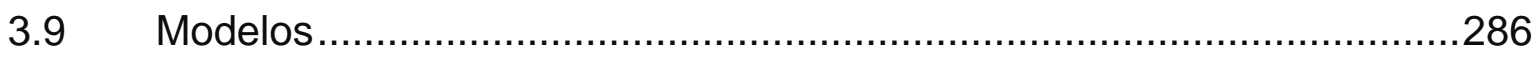

3.9.1 Proibição do défice relacionada com a proporcionalidade ....................287

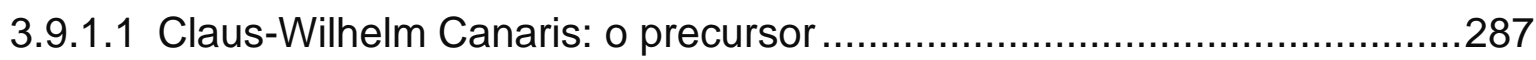

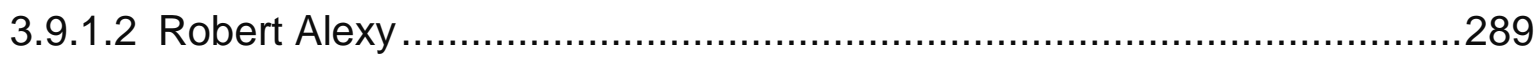

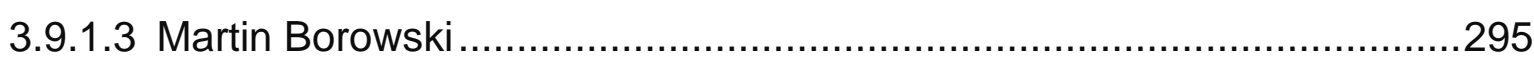

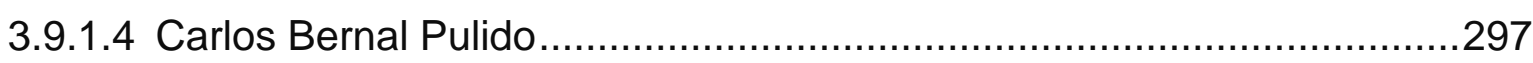

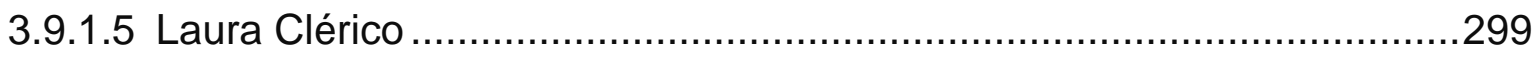

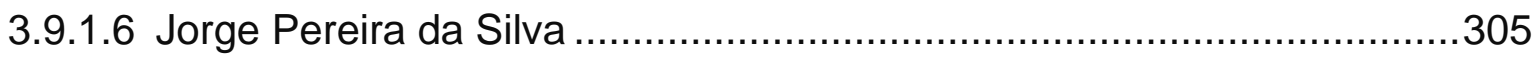

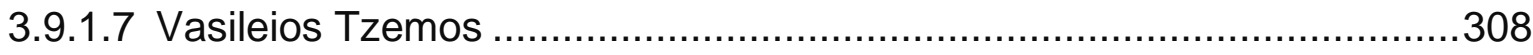

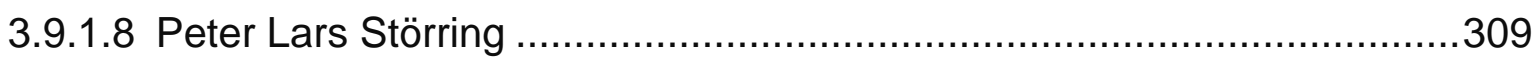

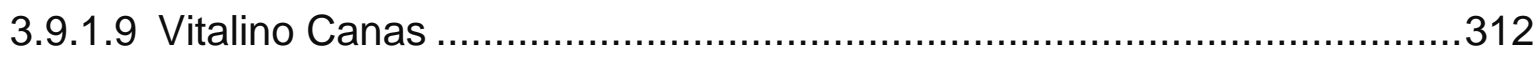

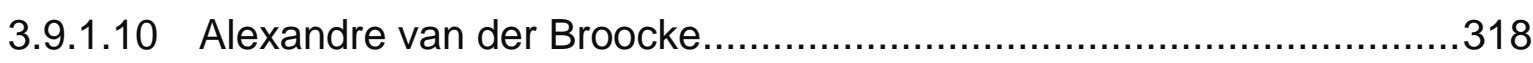

3.9.2 Proibição do défice sem relação com a proporcionalidade .....................319

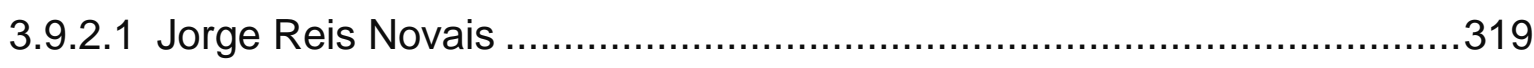

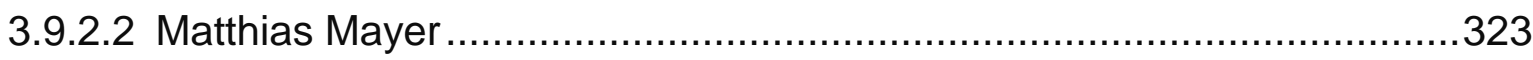

4 VIABILIDADE DO CONTROLE DE INSUFICIÊNCIA NO DIREITO

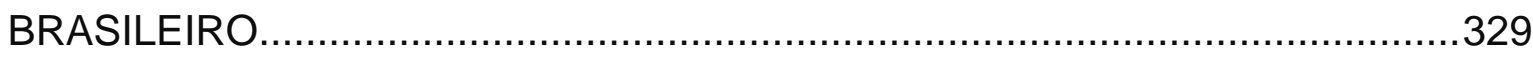

4.1 Visão pessoal sobre a proibição de insuficiência ...................................329 
4.1.1 Premissas teórico-dogmáticas de ordem geral ..................................... 329

4.1.2 Premissas teórico-dogmáticas de ordem específica ................................334

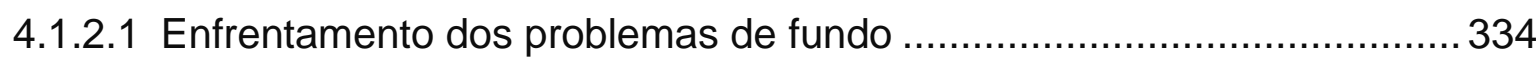

4.1.2.2 Ausência de critérios consolidados na doutrina e jurisprudência pátrias 361

4.1.3 Modelo de controle da proibição da proteção deficiente proposto ..........366

4.1.3.1 Primeira análise preliminar: exame da legitimidade do meio e do fim.... 366

4.1.3.2 Segunda análise preliminar: proibição de excesso ou insuficiência?.....369

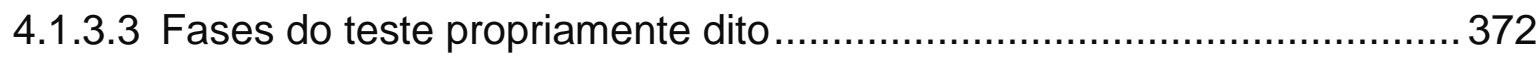

4.1.3.4 Consequências do reconhecimento da insuficiência................................390

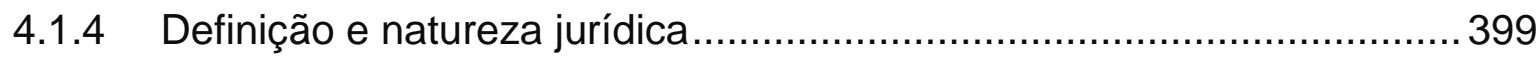

4.2 Proteção de insuficiência aplicada às normas sobre responsabilidade civil

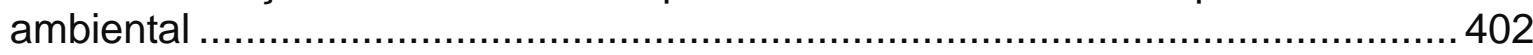

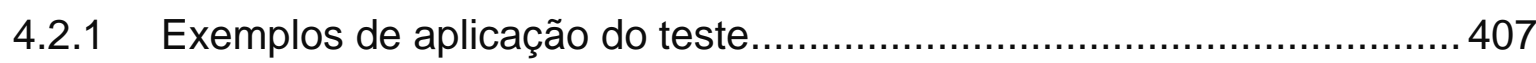

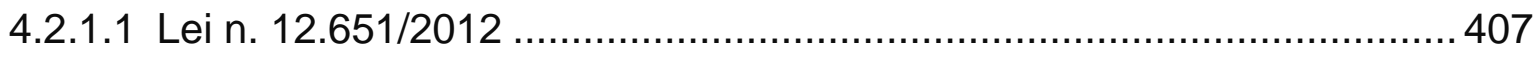

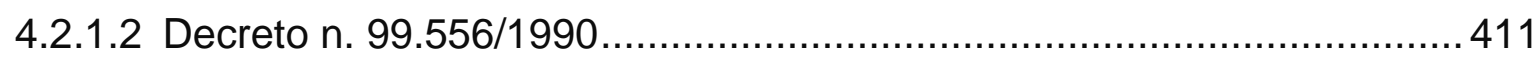

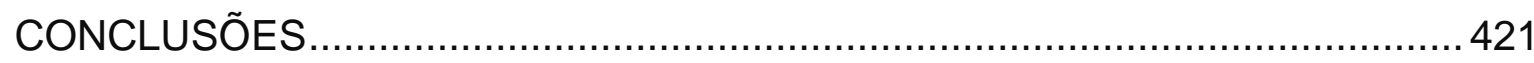

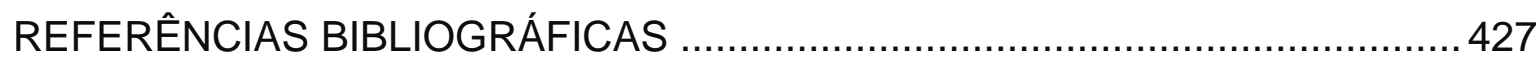




\section{INTRODUÇÃO}

A Constituição Federal de 1988, a exemplo de muitas congêneres proclamadas após a segunda guerra mundial, é repleta de normas de baixa densidade normativa. Típicas dessa estrutura normativamente porosa são as normas veiculadoras de direitos fundamentais. Cumpre primordialmente ao legislador colmatar os vazios por elas deixados, harmonizando interesses que, deixados ao sabor dos preceitos constitucionais de tal gênero, poderiam ensejar conflitos, dada a potencial interpenetração dos respectivos âmbitos de proteção. No desempenho desse mister, não raro o legislador extravasa os limites constitucionais de sua margem de discricionariedade, e, ainda que buscando um fim constitucionalmente legítimo, acaba por comprimir desproporcionalmente algum direito fundamental.

Não por acaso, a partir de meados do século passado, o gênio acadêmico e jurisprudencial passou a se preocupar com eventuais abusos praticados a pretexto dessa missão legislativa. Para coibi-los, reconheceu haver lastro constitucional na imposição de um limite à intervenção legislativa em direitos fundamentais, que ficou conhecido entre nós como proibição do excesso, e na Alemanha, seu principal propulsor de origem, é denominado Übermaßverbot. A fim de controlá-lo judicialmente, desenvolveram-se metodologias orientadas por um controle de proporcionalidade.

Já na década de 1980, ainda em solo germânico, percebeu-se também ser necessário examinar esse trabalho legislativo no sentido oposto. Em outros termos, em contextos de colisão entre dois diretos fundamentais, era preciso fiscalizar se o Estado-legislador, alegando evitar uma interferência abusiva no âmbito de um direito fundamental, não estaria deixando de proteger suficientemente o outro. Nesse caso, afirmou-se existir, também, uma proibição de proteção insuficiente (proibição de insuficiência ou do défice), ou Untermaßverbot, em alemão.

Desde então, essa nova figura dogmática foi adotada pela doutrina e jurisprudência germânicas e lusitanas, mas ainda é carente de aprofundamento teórico no Brasil. Mesmo em sua terra natal, onde a produção acadêmica pertinente é relativamente ampla, há significativas divergências na definição de critérios para a avaliação da omissão estatal na proteção de direitos fundamentais em geral, e do 
direito ao meio ambiente em especial.

Sem embargo da ausência de um tratamento uniforme no campo alienígena e do referencial teórico nacional relativamente escasso, adotou-se como hipótese desta investigação que a vedação do défice, sob o sistema jurídico brasileiro, teria grande potencial como instrumento de controle da omissão estatal no desempenho de seus deveres constitucionais de ação, e, mais especificamente, do dever de tutela do meio ambiente, notadamente por meio da responsabilidade civil ambiental. Por isso, esta pesquisa se propôs a estudar a utilidade dessa nova categoria jurídica para tais propósitos. Seu objetivo foi o de identificar critérios minimamente racionais para detectar eventual insuficiência na atuação estatal, à luz dos parâmetros constitucionais da disciplina da responsabilidade civil ambiental, sem abdicar de eventuais limites à ação corretiva do Estado-juiz, em respeito à primazia dos órgãos democraticamente eleitos para a concretização dos direitos fundamentais.

A título basilar, foram investigadas as principais características do direito fundamental ao meio ambiente saudável e do dever de protegê-lo, tendo em vista que a responsabilidade civil ambiental the tem caráter instrumental. Considerandose as peculiaridades associadas a essas categorias jurídicas, examinaram-se, em linhas gerais, as expressões da responsabilidade civil não apenas na tradicional função de reparação, como também de prevenção de danos ambientais.

Adicionalmente, analisaram-se os desenvolvimentos doutrinário e jurisprudencial da proibição da proteção insuficiente - a partir da teoria dos deveres estatais de proteção - e as críticas à sua admissibilidade ou utilidade como ferramenta de controle de proporcionalidade. Sem descurar as possíveis contribuições que a doutrina e a jurisprudência estrangeiras pudessem aportar, a pesquisa observou as fronteiras do ordenamento jurídico brasileiro. À evidência, portanto, o empréstimo de construções teóricas ou dogmáticas exógenas considerou sua compatibilidade com a realidade jurídica nacional.

A pesquisa foi conduzida eminentemente no âmbito da dogmática jurídica. Tratou-se de uma investigação predominantemente teórico-dogmática, em que se procedeu a investigações bibliográfica (doutrinária) e documental (normas e jurisprudência), no âmbito nacional e internacional, no fito de apurar o estado da arte na doutrina relacionada com a proteção ao direito fundamental ao meio 
ambiente ecologicamente equilibrado, o que inclui a responsabilidade civil ambiental e, sobretudo - em razão de ser o tema menos desenvolvido no âmbito nacional - da proibição da proteção insuficiente.

A distribuição dos capítulos foi organizada em razão de se trabalhar com a hipótese de que as objeções doutrinárias à viabilidade ou à utilidade da aferição da suficiência do nível de proteção normativo a direitos fundamentais, no caso específico do direito fundamental ao meio ambiente saudável, poderiam ser reduzidas ou eliminadas a partir da consideração das peculiaridades desse direito fundamental e da correlativa responsabilidade civil no nosso ordenamento. Além disso, considerou-se que tais particularidades poderiam impactar em alguma medida a estruturação do método de controle da proibição do défice.

No primeiro capítulo, portanto, expuseram-se noções gerais sobre os direitos fundamentais, tais como sua evolução histórica e seus pressupostos filosóficos, suas manifestações subjetivas e objetivas, seus titulares e destinatários, dentre outros assuntos. Posteriormente, abordaram-se os atributos do direito fundamental ao meio ambiente, e, por fim, os deveres fundamentais a ele correlatos.

O segundo capítulo teve por propósito o de identificar os atributos de maior relevância para o balizamento da responsabilidade civil como instrumento de proteção suficiente do direito fundamental ao meio ambiente. Descreveram-se em linhas suas potencialidades como instrumento de prevenção e reparação do dano ambiental, e expuseram-se peculiaridades de sua natureza objetiva, seus princípios reitores e pressupostos de aplicação, dentre outras.

No terceiro capítulo, foram apresentados, de modo panorâmico, as origens e desenvolvimentos doutrinários e jurisprudenciais da proibição da insuficiência na Alemanha, Portugal e Brasil. Polêmicas sobre sua autonomia dogmática em relação a outras categorias, bem como problemas de fundo gerados pela necessidade de preservação da margem de discricionariedade do legislador e uma suposta orientação liberal dos direitos fundamentais, também foram tratados. Foram exibidos, por fim, a visão de vários autores acerca do modelo ideal de aplicação do instituto.

O derradeiro capítulo expôs a concepção do autor sobre a proibição do défice à luz do arcabouço dogmático nacional. Os problemas de fundo, introduzidos no 
capítulo anterior, foram criticamente enfrentados. Defendeu-se um modelo estruturalmente pensado para o controle da proibição de insuficiência, com ênfase nas peculiaridades relacionadas à revisão judicial de normas que afetem a responsabilidade civil ambiental. Por fim, o modelo foi aplicado, a título de demonstração, a algumas normas portadoras de colisões entre o dever de proteção do meio ambiente, via responsabilidade civil, e outros bens constitucionais. 


\section{CONCLUSÕES}

Embora a proibição de insuficiência seja uma figura dogmática concebida sob outras coordenadas jurídicas, os mesmos fundamentos que amparam sua aplicabilidade em solo estrangeiro são aproveitáveis no âmbito doméstico. As novas funções decorrentes da dimensão objetiva dos direitos fundamentais são construções perfeitamente compatíveis com o perfil constitucional dos direitos fundamentais plasmados em nossa Carta Política, e, ao conferirem lastro não apenas para os deveres estatais de proteção, como também para prestações positivas em geral, corroboram o fundamento remoto da incidência da vedação do défice: a existência de deveres estatais positivos.

Como se não bastasse, nossa Constituição é contundente em impelir o Estado à ação, e o faz de forma muito mais intensa que a Lei Fundamental alemã. Desde o preâmbulo, os Poderes estatais são instados a assegurar o exercício dos direitos sociais e individuais, a liberdade, a segurança, 0 bem-estar, 0 desenvolvimento, a igualdade e a justiça como valores supremos da sociedade, tarefa que não se realiza sem atuações positivas. Para além desse vetor interpretativo, a eficácia imediata dos direitos fundamentais e a previsão de diversos procedimentos específicos para o controle da omissão estatal não deixam dúvida de que ao Estado brasileiro não basta se abster de comprimir liberdades fundamentais, devendo, além disso, atuar positivamente para satisfazer direitos fundamentais positivos. E, especificamente em relação ao meio ambiente, nossa ordem constitucional impõe explicitamente ao Estado o dever de protegê-la, inclusive por meio da responsabilidade civil.

Por outro lado, nossa Norma Fundamental, como muitas congêneres de seu tempo, é o resultado do amálgama de uma pluralidade de aspirações contrastantes, que não poderiam ser organizadas num mesmo texto constitucional sem o vasto recurso a normas prima facie. O esforço de condensação do seu conteúdo normativo foi remetido, em primeira linha, ao legislador ordinário, que, nesse mister, inevitavelmente, acabará por vezes navegando em zonas cinzentas, em que os potenciais âmbitos de aplicação de direitos fundamentais e outros bens constitucionais podem se sobrepor. Na tarefa de harmonização entre os direitos ou bens prima facie conflitantes, ante a ausência de um conteúdo definitivo das 
normas em questão, não há como o legislador se valer de operações lógicodedutivas: ele há que lançar mão de juízos de proporcionalidade. Do mesmo modo, o Judiciário poderá ser chamado a verificar se o parlamento (ou, quando o caso, o Executivo), nessa função, não desbordou os limites de sua liberdade de conformação, e, não terá outra forma de fazê-lo que não por meio de um controle de proporcionalidade.

O controle de proporcionalidade desenvolvido para controlar intervenções excessivas do Estado nas liberdades fundamentais não foi talhado para avaliar os comandos normativos prima facie que exigem atuações estatais positivas. A imprescindibilidade dessa aferição fornece um fundamento imediato para proibição de atuação insuficiente como instrumento de controle de proporcionalidade. $\mathrm{E}$ a necessidade de que esse exame seja feito sob uma ótica de proporcionalidade condiciona a estruturação do modelo de controle a ser desenvolvido para a proibição da insuficiência.

Mesmo atrelada a um exame de proporcionalidade, a vedação do défice não se confunde com a proibição do excesso, tampouco com ela converge num mesmo ponto. Além disso, essa nova figura agrega mais valia dogmática em relação à teoria dos deveres de proteção, e tampouco pode ser reduzida ao conteúdo essencial dos direitos fundamentais.

Um controle de proporcionalidade só precisa ser realizado se a norma infraconstitucional sob exame for legítima quanto ao meio e ao fim. Além disso, para saber se o controle de proporcionalidade deve perscrutar a proibição do excesso ou da insuficiência, é preciso considerar a estrutura deôntico-normativa do conflito: caso ele seja entre um dever de ação e outro dever (de ação ou abstenção) ou permissão, a hipótese é de proibição de insuficiência; caso a colisão se dê entre um dever de abstenção e uma permissão, o enfoque é de proibição do excesso.

A preservação da margem de discricionaridade do legislador e a necessidade de preservação de uma orientação liberal dos direitos fundamentais não justificam que o Judiciário, na revisão da insuficiência dos atos normativos, contenha-se num mero exame de evidência. A separação dos poderes é importante, mas já não pode ser vista como idealmente representada na teoria política, carecendo, antes, de levar em conta o funcionamento dos ramos estatais 
no mundo real e as peculiaridades de cada sistema político. Os déficits de representatividade dos órgãos eleitos e a importância democrática de instrumentos contramajoritários atenuam, em muito, os argumentos pela autocontenção do Judiciário. Por outro lado, nossa Constituição não é uma constituição é uma constituição-fundamento, em não uma constituição-moldura. O Brasil é um Estado social e democrático de direito, em que os direitos fundamentais de orientação liberal têm de conviver com outros, que clamam pela atuação estatal positiva, e têm, tanto quanto os liberais, aplicabilidade imediata.

Assim como o controle na proibição do excesso, a melhor racionalidade operacional do teste da proibição de insuficiência recomenda uma estrutura trifásica. Ele deve ser composto pelos testes da adequação, eficiência exigível e proporcionalidade em sentido estrito, aplicáveis nessa sequência. Havendo aprovação num deles, passa-se ao subsequente. Aprovada em todos, a norma será constitucional, e terá respeitado a proibição do défice. Havendo reprovação em qualquer deles, a norma será desproporcional, por violação àquela regra.

No exame da adequação, haverá aprovação caso a norma seja apta a promover, em alguma medida, o fim por ela visado. Esse subteste não é aplicado em casos de omissão total. Afinal, toda omissão total é sempre idônea a fomentar o fim contraposto ao dever de ação. No exame de eficiência exigível, haverá aprovação se preenchidos dois requisitos: i) inexistência de outro meio que, afetando negativamente menos ou promovendo mais o dever de ação, satisfaçam, pelo menos em igual medida, os deveres ou interesses colidentes; ii) inexistência de outro meio que, promovendo mais o dever ou interesse colidente, prejudique menos ou em igual medida o dever de ação. Por fim, no subteste da proporcionalidade em sentido estrito, deverá ser apurado eventual desequilíbrio entre a importância social produzida pela norma sobre o dever de ação relativamente e a importância social por ela acrescida ao dever ou interesse colidente. $\mathrm{Na}$ aferição das respectivas importâncias sociais, deverão ser considerados a importância constitucional abstrata dos bens em conflito, a intensidade do saldo (positivo ou negativo) dos efeitos sobre eles produzidos pela norma em exame, e o grau de certeza sobre as premissas empíricas (diagnósticos e prognósticos) que levaram à mensuração daquelas intensidades. 
Aliás, o grau de convicção sobre os diagnósticos e prognósticos também é relevante nos testes da adequação e da eficiência exigível, sendo necessário aferir se o ente elaborador da norma tomou as devidas cautelas para a coleta do material disponível, à época, para a tomada de decisão. Cumpre apurar, também, a partir de critérios objetivos, o grau de credibilidade científica do suporte informacional que lastrou os diagnósticos e prognósticos, bem como se não há claro equívoco do legislador.

A responsabilidade civil é uma ferramenta imprescindível à garantia do direito fundamental ao meio ambiente ecologicamente equilibrado, e, em função das acentuadas transformações sociais, econômicas e, principalmente, tecnológicas experimentadas pela humanidade desde o início da revolução industrial, já há tempos que não pode ser reduzida à função de proteção secundária. Em vez disso, inspirada, sobretudo, pelo princípio da precaução, é possível defender uma responsabilidade civil preventiva, não a ponto de supor indenizável o risco de dano, mas o bastante para permitir a cominação de sanções voltadas a evitar que esse risco se transforme no mal por ele prenunciado.

Muitos dos atributos da responsabilidade civil ambiental têm pontos de apoio na Constituição. Alguns deles têm estrutura de regra, como o caráter objetivo da responsabilidade civil, o dever de reparação integral e a imprescritibilidade da pretensão reparatória. Portanto, normas ordinárias que os afrontarem serão inconstitucionais, sendo suficiente, para tal constatação, um juízo de subsunção. Diferentemente, outras normas constitucionais sobre o tema são prima facie. É o caso dos princípios da precaução, do poluidor-pagador, e do próprio caput do art. 225, que, ao impor o dever de proteção do meio ambiente, indica uma preferência por uma compensação com alguma conexão ecológica com o bem agravado, embora sem emitir um comando definitivo nesse sentido.

Normas infraconstitucionais que afrontem normas constitucionais prima facie pertinentes à responsabilidade civil ambiental são, ao mesmo tempo, ofensivas ao direito ao meio ambiente como um todo, já que as normas constitucionais sobre responsabilidade civil ambiental são parte daquele direito fundamental completo. Dentre as relações existentes entre as diversas posições jurídicas hospedadas no direito fundamental ao ambiente como um todo (completo), a responsabilidade civil 
é instrumental em relação ao direito ao ambiente como direito a algo. Dada, portanto, a função eminentemente protetiva dessa norma, caso seja ela prima facie, normas infraconstitucionais que busquem reduzir seu alcance abrirão um conflito em que num dos polos haverá um dever estatal de ação (proteção do meio ambiente), convocando um exame de proporcionalidade sob a ótica a proibição de insuficiência.

As características do direito fundamental ao meio ambiente e dos princípios que o orientam, e, consequentemente, que também regem a responsabilidade civil ambiental, exercem impacto sobre dogmática da proibição de insuficiência. O dever de proteção ambiental, expressamente assentado no texto constitucional, e o caráter prima facie de várias de suas normas, corrobora a existência da regra de proibição do défice. A proximidade do direito ao meio ambiente com o princípio fundamental da dignidade e o princípio da precação exigem que o controle da insuficiência seja digno desse nome, assumindo, portanto, um exame com intensidade de justificabilidade, sendo inadmissível um mero exame de evidência. Pela mesma razão, impõe-se o escrutínio da diligência dos responsáveis pela elaboração do ato normativo na coleta dos subsídios informacionais disponíveis sob o estado da arte técnico-científica. O direito das futuras gerações impõe que, nos diversos subtestes do controle do défice, um largo espectro de temporalidade seja levado em conta no prognóstico da manifestação dos danos e do seu tempo de reparação. 
426 


\section{REFERÊNCIAS BIBLIOGRÁFICAS}

ABOUD, Georges. Processo Constitucional Brasileiro. 3. ${ }^{a}$ ed. São Paulo: Revista dos Tribunais, 2019.

ALENCASTRO, Catarina. "Código Florestal: segundo pesquisa Datafolha, 79\% dos brasileiros são contra perdão de multas a quem desmatou ilegalmente". $O$ Globo "on line", 10.06.2011. Disponível em: https://oglobo.globo.com/politica/codigo-florestal-segundo-pesquisa-datafolha79-dos-brasileiros-sao-contra-perdao-de-multas-quem-desmatou-ilegalmente2876725. Acesso em: 08.12.2019.

ALEXY, Robert. A Theory of Constitutional Rights. Trad. Julia Rivers. New Yourk: Oxford University Press, 2002.

. "Direito Constitucional e Direito Ordinário. Jurisdição Constitucional e Jurisdição Especializada". Revista dos Tribunais. Trad. Luíz Afonso Heck. São Paulo: Revista dos Tribunais, v. 799, mai. 2002

. "Zur Struktur der Grundrechte auf Schutz", in:SIECKMANN, Jan-R (org.). Die Prinzipientheorie der Grundrechte. Baden Baden: Nomos, 2007.

. "La Fórmula del Peso". In: CARBONELL, Miguel (coord.). El Principio de Proporcionalidad em el Estado Constitucional. Bogotá: Universidad Externado de Colombia, 2007. Formato e-Pub.

. "Verfassungsrecht und einfaches Recht - Verfassungsgerichtsbarkeit und Fachgerichtsbarkeit". Veröffentlichungen der Vereiinigung der Deutschen Staatsrechtslehrer. [s.I.]: de Gruyter, 2013. Formato pdf.

. Teoria dos direitos fundamentais. 2. ${ }^{a}$ ed. Trad. Virgílio Afonso da Silva. São Paulo: Malheiros, 2017.

. "Princípios Formais", in: TRIVISONNO, Alexandre T. G.; SALIBA, Aziz Tuffi; LOPES, Mônica S. (org.). Princípios Formais e outros aspectos da Teoria Discursiva do Direito. 2. a ed. Rio de Janeiro: Forense, 2018.

ANDRADE, Adriano; ANDRADE, Landolfo; MASSON, Cleber. Interesses Difusos e Coletivos. 9. ${ }^{a}$ ed. São Paulo: Método, 2019.

Tutela do Patrimônio Ambiental Espeleológico no Direito Material Brasileiro. Dissertação de Mestrado. São Paulo: PUC, 2012.

ANDRADE, André Gustavo Corrêa de. Dano Moral e Indenização Punitiva: os punitive damages na experiência do common law e na perspectiva do direito brasileiro. Rio de Janeiro: Lumen juris, 2009.

ANDRADE, José Carlos Vieira de. Os Direitos Fundamentais na Constituição Portuguesa de 1976. 5. ${ }^{\mathrm{a}}$ ed. Coimbra: Almedina, 2017.

ANDRADE, Landolfo. O Ônus da Prova na Ação Civil Pública. São Paulo: Verbatim, 2015.

ANTUNES, Paulo de Bessa. "Poder Judiciário e Reserva Legal: análise de recentes decisões do Superior Tribunal de Justiça". Revista de Direito Ambiental. São Paulo: Revista dos Tribunais, n. 21, jan./mar., 2001 
. Direito Ambiental. 12. a ed. Rio de Janeiro: Lumen Juris, 2010.

2015.

. Dano Ambiental: uma abordagem conceitual. 2." ed. São Paulo: Atlas,

ARAGÃO, Jarbas. "Bancada Evangélica se une a Ruralistas para Derrotar o Governo". Gospel Prime. 17.mar.2012.

Disponível em: https://www.gospelprime.com.br/bancada-evangelica-se-une-a-ruralistas-paraderrotar-governo/. Acesso em: 12.12.2019.

ARRUDA, Domingos Sávio de Barros. A Categoria Acautelatória da Responsabilidade Ambiental. Revista dos Tribunais Online, pub. orig. in: Revista de Direito Ambiental. São Paulo: Revista dos Tribunais, n. 42, abr./jun., 2006 (paginação da versão eletrônica difere da versão impressa). Disponível em: www.rtonline.com.br. Acesso em 26.11.2019.

ASCENÇÃO, José de Oliveira. As Relações Jurídicas Reais. Lisboa: Livraria Morais, 1962.

ATHIAS, Jorge Alex Nunes. "Responsabilidade Civil e Meio-Ambiente - Breve Panorama do Direito Brasileiro", in: BENJAMIN, Antonio Herman V. (coord.). Dano ambiental: Prevenção, Reparação e Repressão. São Paulo: Revista dos Tribunais, v. 2, 1993.

AZEVEDO, Antonio Junqueira de. "Por uma nova categoria de dano na responsabilidade civil: o dano social". Revista Trimestral de Direito Civil. IBDCivil, v. 19, jul/set-2004.

BACHOF, Otto. Grundgesetz e Potere del Giudice. Trad. Giuliana Stella. Modena: STEM Mucchi, 2017.

BARAK, Aharon. Proportionality - Constitutional Rights and their Limitations. Trad. Doron Kalir. New York: Cambridge University Press, 2012.

BARBOSA, Haroldo Camargo. "O instituto da prescrição aplicado à reparação dos danos ambientais". Revista de Direito Ambiental. São Paulo: Revista dos Tribunais, n. 59, jul./set. 2010.

BARROS, Sérgio Resende de. Direitos Humanos: paradoxo da civilização. Belo Horizonte: Del Rey, 2003.

BARROSO, Luís Roberto. "A Proteção do Meio Ambiente na Constituição Brasileira", in: MILARÉ, Édis; MACHADO, Paulo Affonso Leme (org.). Fundamentos do Direito Ambiental. (Coleção doutrinas essenciai, Direito Ambiental, v. 1). São Paulo: Revista dos Tribunais, 2011.

O Controle de Constitucionalidade no Direito Brasileiro: exposição sistemática da doutrina e análise crítica da jurisprudência. 7.ㄹ ed. São Paulo: Saraiva, 2016. Formato Kindle.

Curso de Direito Constitucional Contemporâneo: os conceitos fundamentais e a construção do novo modelo. 8. ${ }^{a}$ ed. São Paulo: Saraiva Educação, 2019. Formato Kindle.

BARCELLOS, Ana Paula de. Comentários ao Preâmbulo, in: CANOTILHO, J. J. Gomes; MENDES, Gilmar Ferreira; SARLET, Ingo Wolfgang 
et. al. Comentários à Constituição do Brasil. 2.․ ed. São Paulo: Saraiva Educação, 2018 (Série IDP).

BASTOS, Celso Ribeiro; MARTINS, Ives Gandra. Comentários à Constituição do Brasil. 2. a ed. São Paulo: Saraiva, v. 2, 2001.

BECHARA, Erika. Licenciamento e Compensação Ambiental. São Paulo: Jurídica Atlas, 2009.

BECK, Ulrich. Risk Society: Towards a New Modernity. Trad. Mark Ritter. Los Angeles-London-New Delhi: Sage, 1992.

BEILFUSS, Markus González. El Principio de Proporcionalidad em la Jurisprudencia del Tribunal Constitucional. 2.ㄹ ed. Pamplona: Aranzadi, 2015.

BELTRÃO, Antonio F. G. Curso de Direito Ambiental. Rio de Janeiro: Forense; São Paulo: Método, 2009.

BENJAMIN, Antonio Herman V. "Função Ambiental". In: BENJAMIN, Antonio Herman V. (coord.). Dano ambiental: Prevenção, Reparação e Repressão. São Paulo: Revista dos Tribunais, v. 2, 1993.

. "Reflexões sobre a Hipertrofia do Direito de Propriedade na Tutela da Reserva Legal e das Áreas de Preservação Permanente". Revista de Direito Ambiental. São Paulo: Revista dos Tribunais, n. 4, out./dez. 1996,

"Responsabilidade Civil pelo Dano Ambiental". Revista de Direito Ambiental. São Paulo: Revista dos Tribunais, n. 9, jan./mar.1998.

BERNARDO, Wesley de Oliveira Louzada. Dano Moral: Critérios de Fixação de Valor. Rio de Janeiro-São Paulo-Recife: Renovar, 2005.

BEVILÁCQUA, Clóvis. Em defeza do projecto de Código Civil Brazileiro. Rio de Janeiro, São Paulo, Belo Horizonte: Livraria Francisco Alves, 1906.

BICKEL, Alexander. The Least Dangerous Branch: the Supreme Court at the Bar of Politics. 2.. ed. New Haven-Londres: Yale University Press, 1986.

BITTAR, Carlos Alberto. Reparação Civil por Danos Morais. 3.ㄹ ed. São Paulo: Revista dos Tribunais, 1999.

. "Introdução ao Direito Ambiental Brasileiro", in: MILARÉ, Édis; MACHADO, Paulo Affonso Leme (org.). Fundamentos do Direito Ambiental. (Coleção doutrinas essenciais, Direito Ambiental, v. 1). São Paulo: Revista dos Tribunais, , 2011.

BIRNIE, Patricia; BOYLE, Alan; REDGWELL, Catherine. International Law \& the Environment. 3.. ed. New York: Oxford University Press, 2009.

BLECKMANN, Albert. "Neue Aspekte der Drittwirkung der Grundrechte". Deutsches Verwaltungsblatt. Köln-Berlin-Bonn-München: Carl Heymanns Verlag, out. 1998.

BOBBIO, Norberto. A Era dos Direitos. Trad. Carlos Nelson Coutinho. Apres. Celso Lafer. Nova ed. Rio de Janeiro: Elsevier, 2004.

BÖCKENFÖRDE, Ernst-Wolfgang. "Grundrechte als Grundsatznormen: Zur gegenwärtigen Lage der Grundrechtsdogmatik", in: Der Staat. [s.I.]: Duncker 
und Humblot, v. 29, n. 1, 1990. Disponível em: www.jstor.org/stable/43642245. Acesso em 09.07.2018.

"Schutzbereich, Eingriff, Verfassungsimmanente Schranken: Zur Kritik Gegenwärtiger Grundrechtsdogmatik". Der Staat, v. 42, n. 2, 2003. Disponível em: www.jstor.org/stable/43643422. Acesso em: 28.08.2019.

"Fundamental Rights as Constitutional Principles", in: Constitutional Political Theory: selected writings. Trad. por Thomas Dunlap. Oxford-New York: Oxford University Press, 2016.

BONAVIDES, Paulo. Curso de direito constitucional. 24. ㄹ ed. São Paulo: Malheiros, 2009.

BORGES, Roxana Cardoso Brasileiro. Função ambiental da propriedade rural. São Paulo: LTr, 1999.

BOROWSKI, Martin. Grundrechte als Prinzipien. 2. a ed. Baden-Baden: Nomos, 2007.

BOSSELMANN, Klauss. The Principle of Sustainability: transforming law and governance. Hampshire, Burlington: Ashgate, 2008.

"Direitos Humanos, Meio Ambiente e Sustentabilidade", in: SARLET, Ingo Wolfgang (org.), Estado Socioambiental e Direitos Fundamentais. Porto Alegre: Livraria do Advogado, 2010.

BOUTONNET, Mathilde. "L'influence du Principe de Précaution sur la Responsabilité Civile en Droit Français: un bilan en demi-teinte". McGill International Journal of Sustainable Development Law and Policy/Revue Internationale de Droit et Politique du Développement Durable de McGill. v. 10, n. 1, 2014. Disponível em: http://www.jstor.org/stable/24352836. Acesso em: 01.11.2019.

BOYD, David R. "Catalyst for Change - Evaluating Forty Years of Experience in Implementing the Right to a Healthy Environment", in: KNOX, John H; PEJAN, Ramin (ed.). The Human Right to Health Environment. New York: Cambridge University Press, 2018. Formato Kindle.

BRANDÃO, Paulo de Tarso. A Tutela Judicial dos "Novos" Direitos: em busca de uma efetividade para os direitos típicos da cidadania. Tese de Doutorado. Florianópolis: Universidade Federal de Santa Catarina, 2000. Disponível em: https://repositorio.ufsc.br/bitstream/handle/123456789/79158/175313.pdf?seq uence $=1$ \&isAllowed=y. Acesso em: 02.06.2018.

BREUER, Rüdiger. "Staatsrecht und Gerechtigkeit”, in: BENDER, Bernd; BREUER, Rüdiger; OSSENBÜHL, Fritz et al (Hrsg.). Rechtsstaat zwischen Sozialgestaltung und Rechtsschutz: Festschrift für Konrad Redeker zum 70. Geburtstag, München: C.H. Beck, 1993.

BUNAZAR, Maurício. Obrigação propter rem: aspectos teóricos e práticos. São Paulo: Atlas, 2013.

CABALLERO, Francis. Essai sur la Notion Juridique de la Nuisance. Paris: Librairie générale de droit et de jurisprudence, 1981. 
CAFFERATTA, Néstor A. "Prueba y nexo de Causalidad em el Daño Ambiental", in: BENJAMIN, Antonio H.; LECEY, Eladio; CAPPELLI, Silvia (orgs.). Congresso Internacional de Direito Ambiental. São Paulo: IMESP, v. 1, 2007.

CAHALI, Yussef Sahid. Responsabilidade Civil do Estado. 3. ${ }^{a}$ ed. São Paulo: Revista dos Tribunais, 2007.

CALLIESS, Christian. Rechtsstaat und Umweltstaat: zugleich ein Beitrag zur Grundrechtsdogmatik im Rahmen mehrpoliger Verfassungsverhältnisse. Tübingen: Mohr Siebeck, 2001.

"Schutzpflichten", in: MERTEN, Detlef; PAPIER, Hans-Jürgen (Hg.). Handbuch der Grundrechte in Deutschland und Europa. Heidelberg: C. F. Müller, v. II, 2006.

"Die Leistungsfähigkeit des Untermaßverboptes als Kontrollmaßstab grundrechtlicher Schutzpflichten", in: GROTE, Rainer; HÄRTEL, Ines; HAIN, Karl-E. et al (Hg). Die Ordnung der Freiheit: Festschrift für Christian Starck zum siebzigsten Geburtstag. Tübingen: Mohr Siebeck, 2007.

CAMARGO, Paulo Sérgio Ferraz de. Dano Moral Coletivo: uma possibilidade de aplicação dos danos punitivos. São Paulo: Almedina, 2016.

CANARIS, Claus Wilhelm. "Grundrechte und Privatrecht". Archiv für die civilistische Praxis. [s.l.]: Mohr Siebeck, 184.Bd, 1984. Disponível em: www.jstor.org/stable/40995213. Acesso em: 03.05.2018.

"Erwiderung" in: CANARIS, Claus-Wilhelm; SCHWABE, Jürgen, "Grundrechte und Privatrecht (with Erwiderung)". Archiv für die civilistische Praxis. [s.l.]: Mohr Siebeck, 185.Bd, 1985. Disponível em: www.jstor.org/stable/40995264. Acesso em: 28.03.2019.

"Grundrechtswirkungen und Verhältnismäßigkeitsprinzip in der richterlichen Anwendung und Fortbildung des Privatrechts". Juristische Schulung. München-Frankfurt: C.H. Beck, Heft 3, mar.,1989.

. Grundrechte und Privatrecht. Berlin: de Gruyter, 1999.

. Direitos fundamentais e Direito Privado. Trad. Ingo Sarlet e Paulo Mota Pinto. Coimbra: Almedina, 2003.

CANAS, Vitalino. O Princípio da Proibição do Excesso na Conformação e no Controlo de Atos Legislativos. Coimbra: Almedina, 2017.

CANOTILHO, J. J. Gomes. Direito Constitucional e Teoria da Constituição. 7.. ed. Coimbra: Almedina, 2003.

CAROLAN, Eoin. The New Separation of Powers: a theory for the modern state. Oxford, U.K.,-New York: Oxford University Press, 2009.

CARVALHO, Nelson Rojas de. "Geografia política das eleições congressuais: a dinâmica da representação das áreas urbanas e metropolitanas no Brasil”. Cadernos Metrópole, v. 11, n. 22, ju./dez.2009.

Disponível em: https://revistas.pucsp.br/metropole/article/view/5939/4292. Acesso em: 08.12.2019

CASELLA, Paulo Borba. Direito Internacional no Tempo Medieval e Moderno até Vitória. São Paulo: Atlas, 2012. 
CASTRO, Carlos Roberto Siqueira de. O Devido Processo Legal e os Princípios da Razoabilidade e da Proporcionalidade. 5. ${ }^{a}$ ed. Rio de Janeiro: Forense, 2010.

CASTRO, Fábio de. "Normas para emissões menos poluentes de veículos vigoram a partir de 2023". Direto da Ciência. 28.11.2018. Disponível em: http://www.diretodaciencia.com/2018/11/28/normas-para-emissoes-menospoluentes-de-veiculos-vigoram-a-partir-de-2023/. Acesso em: 14.10.2019.

CATALÀ, Lúcia Gomis. Responsabilidad por Daños al Medio Ambiente. Pamplona: Aranzadi, 1998.

CAVALIERI FILHO, Sérgio. Programa de Responsabilidade Civil. 13. a ed. São Paulo: Atlas, 2019.

CLÉRICO, Laura. "Verhältnismäßigkeitsgebot und Untermaßverbot", in: SIECKMANN, Jan-R (Hrsg.). Die Prinzipientheorie der Grundrechte. BadenBaden: Nomos, 2007.

El Examen de Proporcionalidade en el Derecho Constitucional. Buenos Aires: Eudeba, 2009.

COIMBRA, José de Ávila Aguiar. O Outro Lado do Meio Ambiente. São Paulo: CETESB, 1985.

COMPARATO, Fábio Konder. A Afirmação Histórica dos Direitos Humanos. 11.a ed. São Paulo: Saraiva, 2017.

CORDEIRO, António Menezes. "Tutela do ambiente e direito civil", in: AMARAL, Diogo Freitas do (coord). Direito do ambiente. Lisboa: Instituto Nacional de Administração, 1994.

Tratado de Direito Civil: Direito das Obrigações: gestão de negócios, enriquecimento sem causa, responsabilidade civil. Coimbra: Almedina, v. 8, 2017

DE CICCO, Cláudio. História do Pensamento jurídico e da Filosofia do Direito. 4. a ed. São Paulo: Saraiva, 2008.

DENARI, Zelmo. Comentários ao art. 16, in: GRINOVER, Ada Pelegrini; BENJAMIN, Antônio Herman de V.; FINK, Daniel Roberto Fink et. al. Código Brasileiro de Defesa do Consumidor comentado pelos autores do anteprojeto.

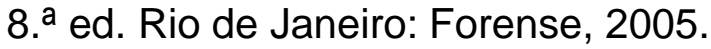

DENNINGER, Erhard. "Vom Elend des Gesetzgebers zwischen Übermaßverbot und Untermaßverbot", In: DÄUBLER-GMELIN, Herta; KINDEL, Klaus; MEYER, Hans et al (Hg.). Gegenrede. Aufklärung - Kritik - Öffentlichkeit: Festschrift für Ernst Gottfried Mahrenholz. Baden-Baden: Nomos, 1994.

DERANI, Derani, Direito Ambiental Econômico. 3. a ed. São Paulo: Saraiva, 2008.

DERBLI, Felipe. "O Papel do Estado-membro no Controle Abstrato de Constitucionalidade das Leis em Matéria de Direitos Fundamentais", in: VENTURA, Zênio; FAGÚNDEZ, Paulo R. Ávila (org.). As Perspectivas da Advocacia Pública e a Nova Ordem Econômica. Florianópolis: OAB/SC, 2006.

DIAS, José de Aguiar. Da Responsabilidade Civil. 11. a ed. rev. e atual. por Rui Berford Dias. Rio de Janeiro: Renovar, 2006. 
DIETLEIN, Johannes. Die Lehre von den grundrechtlichen Schutzpflichten. Berlin: Dunker \& Humblot, 1992.

. "Das Untermaßverbot: Bestandsaufnahme und Entwicklungschancen einer neuen Rechtsfigur". Zeitschrift für Gesetzgebung. Heidelberg: Müller, v. 10, n. 2, 1995.

DIMOULIS, Dimitri; MARTINS, Leonardo. "Deveres Fundamentais", in: LEITE, George Salomão (org.). Direitos, deveres e garantias fundamentais. Salvador: Juspodivm, 2011.

Atlas, 2014.

Teoria Geral dos Direitos Fundamentais. 5. ${ }^{\text {a }}$ ed. São Paulo:

; LUNARDI, Soraya. Curso de Processo Constitucional: controle de constituticionalidade e remédios constitucionais. 6.. ed. São Paulo: Revista dos Tribunais, 2019.

D'ISEP, Clarissa F. M. "O Princípio do Poluidor-Pagador e a sua Aplicação Jurídica: complexidades, incertezas e desafios", In: MARQUES, Cláudia Lima et al. (org.). O Novo Direito Administrativo, Ambiental e Urbanístico - Estudos em homenagem à Jacqueline Morand-Deviller. São Paulo: Revista dos Tribunais, 2010.

DREIER, Horst. Comentários ao art. 19, Abs. II, in: DREIER, Horst (Hrsg.) Grundgesetz Kommentar. 3.ㄹ ed. Tübingen: Mohr Siebeck, v. 1, 2013.

DUGUIT, Leon. Las transformaciones del derecho publico y privado. Buenos Aires: Heliasta, 1975.

DUQUE, Marcelo Schenk. Direito Privado e Constituição: Drittwirkung dos Direitos Fundamentais: construção de um modelo de convergência à luz dos contratos de consumo. São Paulo: Revista dos Tribunais, 2013.

DWORKIN, Ronald. Justice in Robes. Cambridge-London: Belknap, 2006. . Taking Rights Seriously. London-New York: Bloomsbury, 2013. Fomato Kindle.

"Editorial". A Tribuna. Santos, 14.12.2019. Disponível em: http://edicaodigital.atribuna.com.br/pub/tribunadesantos/?numero=43735\&edic $\mathrm{ao}=10423$ \#page/3. Acesso em 15.12.2019.

ELY, John Hart. Democracy and Distrust: a Theory of Judicial Review, Cambridge, Massachussets; London: Harvard University Press, 1980.

ENTERRÍA, Eduardo García de. La Constitución como norma y el Tribunal Constitucional. 3. ${ }^{a}$ ed. Madri: Civitas, 2001.

ERICHSEN, Hans-Uwe. "Die Drittwirkung der Grundrechte". Juristische Ausbildung. Berlin: de Gruyter, 1996.

"Grundrechtliche Schutzpflichten in der Rechtsprechung des Bundesverfassungsgericht". Juristische Ausbildung. Berlin: de Gruyter, 1997.

FACCINI NETO, Orlando. Elementos de uma Teoria da Decisão Judicial: Hermenêutica, Constituição e Respostas Corretas em Direito. Porto Alegre: Livraria do Advogado, 2011. 
FARIA, Flávia. "Confiança na democracia sobe, mas insatisfação com seu funcionamento é de 58\%". Folha de São Paulo "on line", 04.06.2019. Disponível em: https://www1.folha.uol.com.br/poder/2019/06/confianca-na-democraciasobe-mas-insatisfacao-com-seu-funcionamento-e-de-58.shtml. Acesso em: 08.12.2019.

FELDENS,. Direitos Fundamentais e Direito Penal - A Constituição Penal, 2. a ed., Porto Alegre: Livraria do Advogado, 2012. Formato e-Pub.

FENSTERSEIFER, Tiago. Direitos Fundamentais e Proteção do Ambiente: a dimensão ecológica da dignidade humana no marco jurídico-constitucional do Estado Socioambiental de Direito. Porto Alegre: Livraria do Advogado, 2008.

FERRAJOLI, Luigi. "Direitos Fundamentais", trad. Alfredo Copetti Neto, in: FERRAJOLI, Luigi, Por Uma Teoria dos Direitos e dos Bens Fundamentais. Trad. Alexandre Salim; Alfredo Copetti Neto; Daniela Cademartori et al. Porto Alegre: Livraria do Advogado Editora, 2011.

"Teoria dos Direitos Fundamentais", trad. Hemes Zaneti Júnior e Alexandre Salim, in: FERRAJOLI, Luigi, Por Uma Teoria dos Direitos e dos Bens Fundamentais. Trad. Alexandre Salim; Alfredo Copetti Neto; Daniela Cademartori et al. Porto Alegre: Livraria do Advogado Editora, 2011.

FERRAZ, Sérgio. "Responsabilidade Civil por Dano Ecológico". Revista dos Tribunais Online, pub. orig. in: Revista Direito Público. São Paulo: Revista dos Tribunais, n. 49-50, 1979. Disponível em: www.rtonline.com.br. Acesso em: 30.10.2019.

FERREIRA FILHO, Manoel Gonçalves. Direitos Humanos Fundamentais. 15. a ed. São Paulo: Saraiva, 2016.

FIGUEIREDO, Guilherme J. Purvin de. A Propriedade no Direito Ambiental. 4. ed. 2010. São Paulo: Revista dos Tribunais.

FIGUEIREDO, Lúcia Valle. Disciplina Urbanística da Propriedade. São Paulo: Revista dos Tribunais, 1980.

FIORILLO, Celso Antonio Pacheco; RODRIGUES, Marcelo Abelha. Manual de Direito Ambiental e Legislação Aplicável. 2. ㄹ ed. São Paulo: Max Limonad.

FREITAS, Cristina Godoy de Araújo. "Valoração do Dano Ambiental: algumas premissas". MPMG Jurídico Especial. Belo Horizonte: MP/MG. Disponível em: https://aplicacao.mpmg.mp.br/xmlui/bitstream/handle/123456789/1004/Valora ção\%20do\%20dano\%20ambiental_Freitas.pdf?sequence $=1$ Acesso em 05.11 .2019

FREITAS, Juarez. "Princípio da precaução: vedação de excesso e de inoperância". Belo Horizonte, n. 35, ano 8, jan. 2006 Disponível em: <http://www.editoraforum.com.br/bid/bidConteudoShow.aspx?idConteudo=49 314> Acesso em: 24 fevereiro 2010.

Discricionariedade Administrativa e o Direito Fundamental à Boa Administração Pública. São Paulo: Malheiros, 2007.

FREITAS, Luiz Fernando Calil de. Direitos Fundamentais: limites e restrições. Porto Alegre: Livraria do Advogado, 2007. 
FREITAS, Vladimir Passos de. "Matas Ciliares", in: FREITAS, Vladimir P. de. Direito Ambiental em Evolução. Curitiba: Juruá, n. 2, 2000.

. A Constituição Federal e a Efetividade das Normas Ambientais. 3..$^{\text {a }}$ ed. São Paulo: Revista dos Tribunais, 2005.

FURLAN, Anderson; FRACALOSSI, Willam. Direito Ambiental. Rio de Janeiro: Forense, 2010.

GAGLIANO, Pablo Stolze. "A Responsabilidade Extracontratual no Novo Código Civil e o Surpreendente Tratamento da Atividade de Risco". Repertório de Jurisprudência - IOB, n. 19, texto 3/19551, 1. ํquinz. out. 2002.

; PAMPLONA FILHO, Rodolfo, Novo Curso de Direito Civil: responsabilidade civil. 16. ㄹ ed. São Paulo: Saraiva, v. 3, 2018.

GELLERMANN, Martin. Grundrechte im einfachgesetzlichen Gewand. Tübingen: Mohr Siebeck, 2000.

GIUDICELLI, Gustavo Barbosa. Dimensão Objetiva dos Direitos Fundamentais. Rio de Janeiro: Lumen Juris,2017.

GOLDENBERG, Isidoro H. La relación de causalidade en la responsabilidad civil. Buenos Aires: Astrea, 1984.

GOMES, Orlando. Raízes históricas e sociológicas do Código Civil brasileiro. 2. a ed. São Paulo: Martins Fontes, 2006. 2019.

Obrigações. Atual. por Edvaldo Brito. 19. ${ }^{a}$ ed. Rio de Janeiro: Forense,

GONÇALVES, Roberto Gonçalves. Direito Civil Brasileiro: responsabilidade civil. 14.. ed. São Paulo: Saraiva, v.4, 2019. Formato Kindle.

GÖTZ, Volkmar. "Innere Sicherheit", in: ISENSEE, Josef; KIRCHHOF, Paul (Hrsg.). Handbuch des Staatsrechts der Bundesrepublik Deutschland, Heidelberg: C.F. Müller, v. 3, 1988.

GRARE-DIDIER, Clothilde. "La responsabilité civile pour atteinte à l'environnement", in: Le Droit et le Environnement - Journées nationales. Paris: Dalloz, t. XI, 2010.

Disponível em: http://henricapitant.thomasplessis.com/storage/app/media/pdfs/publications/le-droit-etlenvironnement.pdf. Acesso em: 11.11.2019.

GRAU, Eros Roberto. Elementos de Direito Econômico. São Paulo: Revista dos Tribunais, 1981.

A Ordem Econômica na Constituinte de 1988. 19. à ed. São Paulo: Malheiros, 2018.

GRIMM, Dieter. Die Zukunft der Verfassung. 1. ㄹ ed. Frankfurt am Main: Suhrkamp, 1991.

; KIRCHHOF, Paul; EICHBERGER, Michael. Entscheidungen des Bundesverfassungsgerichts. 3. ${ }^{\mathrm{a}}$ ed. Tübingen: Mohr Siebeck, v. 1, 2007.

A função protetiva do Estado. In: SOUZA NETO, Cláudio Pereira de; SARMENTO, Daniel (coords.) In: A Constitucionalização do Direito. Fundamentos Teóricos e Aplicações Específicas. Rio de Janeiro: Lumen Juris, 
2007.

HÄBERLE, Peter. Die Wesensgehaltgarantie des Artikel 19 Abs. 2 Grundgesetz. 2. ${ }^{\text {a }}$ ed. Karlsruhe: C.F. Müller, 1972.

HAIN, Karl Eberhard. "Der Gesetzgeber in der Klemme zwischen Übermaß und Untermaßverbot?”. Deutsches Verwaltungsblatt. Köln-Berlin-Bonn-München: Carl Heymanns, set. 1993.

HENKEL, Silviana L. "Os Novos Contornos da Tutela Jurídica na Sociedade de Risco: dano ambiental futuro e risco de dano". Revista de Direitos Difusos. São Paulo: IBAP, APRODAB, v. 43, jul.-set./1997.

HERMES, Georg. Das Grundrecht auf Schutz von Leben und Gesundheit. Schutzpflicht und Schutzanspruch aus Art.2 Abs. 2 Satz 1 GG. InauguralDissertation. Freiburger Rechts- und Staatswissenschaftliche Abhandlungen. Freiburg: Fakultät der Universität Freiburg, v. 46, depósito em 1985, prova oral em 03.02.1986.

HESSE, Konrad. "Die verfassungsrechtliche Kontrolle der Wahrnehmung grundrechtlicher Schutzpflichten des Gesetzgebers", in: DÄUBLER-GMELIN, Herta; KINKEL, Klaus; MEYER, Hans et al. (Hrsg.). Festschrift für E. G. Mahrenholz. Baden-Baden: Nomos, 1994.

. Elementos de Direito Constitucional da República Federal da Alemanha. Tradução (da 20. ${ }^{a}$ ed. alemã) de Luís Afonso Heck. Porto Alegre: Sérgio Antonio Fabris, 1998.

HUBER, Peter M. Comentário ao Art. 19, Abs. 2, in: HUBER, Peter M.; VOßKUHLE, Andreas (Hrsg.), Christian. Mangoldt/Klein/Starck Grundgesetz Kommentar. 7. a ed. München: C.H. Beck, v. 1, 2018.

HUNT, Lynn. A Invenção dos Direitos Humanos - uma história. Trad. Rosaura Eichenberg. São Paulo: Companhia das Letras, 2009. Formato Kindle.

ISENSEE, Josef. Das Grundrecht auf Sicherheit: zu den Schutzpflichten des freiheitlichen Verfassungsstaates. Ed. amp. Berlin - New York: de Gruyter, 1983.

"Das Grundrecht als Abwehrrecht und als staatliche Schutzpflicht", in: ISENSEE, Josef; KIRCHHOF, Paul (Hrsg.), Handbuch des Staatsrechts der Bundesrepublik Deutschland, v. 5, § 111, Heidelberg: C.F. Müller, 1992.

ITURRASPE, Jorge Mosset. Palestra "Daño Ambiental". Anais do Congresso Internacional de Direito Ambiental. São Paulo: Instituto O Direito por um Planeta Verde, 1997;

JARASS, Hans D. "Grundrechte als Wertentscheidungen bzw. Objektivrechtliche Prinzipien in der Rechtsprechung des Bundesverfassungsgerichts", in: Archiv des öffentlichen Rechts. [s.I.]: Mohr Siebek, v. 110, n. 3, 1985. Disponível em: www.jstor.com/stable/44306390. Acesso em: 31.03.2019.

"Bausteine Einer Umfassenden Grundrechtsdogmatik". Archiv Des Öffentlichen Rechts. [s.l.]: Mohr Siebeck, v. 120, n. 3, 1995. Disponível em: www.jstor.org/stable/44316123. Acesso em 13.08.2019.

JELLINEK, Georg. Sistema dei Diritti Pubblici Subbiettivi. Trad. da 2. ${ }^{\text {a }}$ ed. alemã de 
System des subjektiven öffentlichen Rechts. Milano: Società Editrice Libraria, 1912.

JONAS, Hans. O Princípio Responsabilidade: ensaio de uma ética para a civilização tecnológica. Trad. do orig. alemão Marijane Lisboa, Luiz Barros Montez. Rio de Janeiro: Contraponto, PUC-Rio, 2006.

KANT, Immanuel. Fundamentação Metafísica dos Costumes e outros Escritos. Trad. Leopoldo Holzbach. São Paulo: Martin Claret, 2011.

KERMELE, Nejma. "Bartolomé de Las Casas". Témoigner. Entre histoire et mémoire. 119|2014. Publicado na rede mundial de computadores em 01.01.2016. Disponível em: https://journals.openedition.org/temoigner/1490. Acesso em: 13.06.2018.

KINGREEN, Thorsten; POSCHER, Ralf. Grundrechte Staatsrecht II. 34.. ed., Heidelberg: C. F. Müller, 2018.

KISS, Alexandre. "An introductory note on human right to environment", in: WEISS, Edith Brown (Ed.). Environmental change and international law: New challenges and dimensions. Tokyo: United Nations University, 1992. Disponível em: http://archive.unu.edu/unupress/unupbooks/uu25ee/uu25ee00.htm\#Contents. Acesso em: 29.06.2018.

; BEURIER, Jean Pierre, Droit International de l'Environnement. 3. Paris: Pedone, 2004.

KLATT, Mathias; MEISTER, Moritz. The Constitutional Structure of Proportionality, Oxford, U.K.: Oxford University Press, 2012.

KLEIN, Eckart. "Grundrechtliche Schutzpflichten des Staates". Neue Juristische Wochenschrift. München: C.H. Beck, jul. 1989.

KLEIN, Hans H. "Die grundrechtliche Schutzpflicht". Deutsches Verwaltungsblatt. Köln-Berlin-Bonn-München: Carl Heymanns Verlag, mai. 1994.

KLOEPFER, Michael. Umweltrecht. 4. a ed. Munique: C.H. Beck, 2016.

KOURILSKY, Philippe; VINEY, Geneviève. Le Principe de Precaution - Rapport au Premier Ministre. 15.out.1999. Disponível em: https://www.viepublique.fr/rapport/26392-le-principe-de-precaution-rapport-au-premierministre Acesso em 30.10.2019.

KRELL, Andreas Joachim. "Concretização do dano ambiental: algumas objeções à teoria do 'risco integral'". Revista de Informação Legislativa. Brasília, a. 35, n. 139, jul./set.1998. Disponível em: https://www2.senado.leg.br/bdsf/bitstream/handle/id/385/r13902.pdf? sequence=4\&isAllowed=y. Acesso em: 30.10.2019.

KRINGS, Günter. Grund und Grenzen grundrechtlicher Schutzansprüche, Berlin: Duncker und Humblot, 2003.

LAFER, Celso. A Reconstrução dos Direitos Humanos: um diálogo com o pensamento de Hannah Arendt. São Paulo: Companhia das Letras, 2001.

LAIN, Corinna. "Upside-Down Judicial Review". The Georgetown Law Journal, v. 101, 2012.

Disponível em: 
https://papers.ssrn.com/sol3/papers.cfm?abstract_id=1984060. Acesso em 08.12.2019.

LAURENTIIS, Lucas Catib de. A proporcionalidade no Direito Constitucional: origem, modelos e reconstrução dogmática. São Paulo: Malheiros, 2017.

LEE, Chien-liang. "Grundrechtsschutz unter Untermaßverbot?", in: GROTE, Rainer; HÄRTEL, Ines; HAIN, Karl-E. (Hrsg.). Die Ordnung der Freiheit: Festschrift für Christian Starck zum siebzigsten Geburtstag.

LEITE, José Rubens Morato; DANTAS, Marcelo Buzaglo; FERNANDES, Daniele Cana Verde. "O Dano Moral Ambiental e sua Reparação". Revista de Direito Ambiental, n. 4. São Paulo: Revista dos Tribunais, out./dez.1996.

CARVALHO, Délton Winter de. "Nexo de Causalidade na Responsabilidade Civil por Danos Ambientais". Revista de Direito Ambiental. São Paulo: Revista dos Tribunais, n. 47, jul./set. 2007.

AYALA, Patryck de Araújo. Dano Ambiental: do individual ao coletivo extrapatrimonial. Teoria e Prática. 7.. ed. São Paulo: Revista dos Tribunais, 2015.

Comentários ao art. 225, § 3.․, in: CANOTILHO, J. J. Gomes; MENDES, Gilmar Ferreira; SARLET, Ingo Wolfgang et. al. Comentários à Constituição do Brasil. 2. ㄹ ed. São Paulo: Saraiva Educação, 2018 (Série IDP).

LEIVAS, Paulo Gilberto Cogo. Teoria dos direitos fundamentais sociais. Livraria do Advogado: Porto Alegre, 2006.

LEMIEUX, Scott E.; WATKINS, David J. Judicial Review and Contemporary Democratic Theory: Power, Domination and the Courts. New York-Abingdon: Routledge, 2018.

LEMOS, Patrícia Faga Iglecias. Direito Ambiental: responsabilidade civil e proteção ao meio ambiente. 3. ㄹ ed. São Paulo: Revista dos Tribunais, 2010.

"Responsabilidade Civil e Dano ao Meio Ambiente: novos rumos", in: MILARÉ, Édis; MACHADO, Paulo Affonso Leme (org.). Dano ambiental: responsabilidade em matéria ambiental. (Coleção doutrinas essenciais, Direito Ambiental, v. 5). São Paulo: Revista dos Tribunais, 2011.

. Meio Ambiente e Responsabilidade Civil do Proprietário: análise do nexo causal. 2. ${ }^{a}$ ed. São Paulo: Revista dos Tribunais, 2012.

Resíduos Sólidos e Responsabilidade Civil Pós-consumo. 2.ㄹ ed. São Paulo: Revista dos Tribunais, 2012.

LIMA, Alvino. Culpa e Risco. 2. ㄹ ed. São Paulo: Revista dos Tribunais, 1998.

LOPES, Teresa Ancona. Princípio da Precaução e Evolução da Responsabilidade Civil. São Paulo: Quartier Latin, 2010.

LÓPEZ, Fernando Ramón. "El derecho ambiental como derecho de la función pública de la protección de los recursos naturales", in: MUÑIZ, José Manuel Valle (coord.). La Protección Jurídica del Medio Ambiente. Pamplona: Aranzadi, 1997. 
LÜBBE-WOLFF, Gertrude. Die Grundrechte als Eingriffsabwehrrechte: Strüktur und Reichweite der Eingriffsdogmatik im Bereich staatlicher Leistungen. BadenBaden: Nomos, 1998.

LUCARELLI, Fábio Dutra. "Responsabilidade Civil por Dano Ecológico", in: MILARÉ, Édis; MACHADO, Paulo Affonso Leme (org.). Dano ambiental: responsabilidade em matéria ambiental. (Coleção doutrinas essenciais, Direito Ambiental, v. 5). São Paulo: Revista dos Tribunais, 2011.

MAC CRORIE, Benedita Ferreira da Silva. A vinculação dos particulares a direitos fundamentais. Coimbra: Almedina, 2005.

MACHADO, Marta de Toledo. Proibições de Excesso e Proteção Insuficiente no Direito Penal. São Paulo: Verbatim, 2008.

MACHADO, Paulo Affonso Leme. Direito Ambiental Brasileiro. 26. ㄹ ed. São Paulo: Malheiros, 2018.

MALUF, Carlos Alberto Dabus. Limitações ao Direito de Propriedade. 2. a ed. São Paulo: Revista dos Tribunais, 2005.

MANCUSO, Rodolfo de Camargo. Ação Civil Pública: em defesa do meio ambiente, do patrimônio cultural e dos consumidores. 10. ${ }^{a}$ ed. São Paulo: Revista dos Tribunais. 2007.

MARCHESAN, Ana Maria Moreira; STEIGLEDER, Annelise Monteiro; CAPPELLI, Sílvia. Direito Ambiental. 6. ${ }^{a}$ ed. Curitiba: Verbo Jurídico, 2010.

MARINO, Bruno di; FERRAZ, Álvaro. "A saga jurisprudencial do dano moral coletivo: tinha razão o saudoso ministro Teori Zavascki". Migalhas. 29.mar.2019. Disponível

em: https://www.migalhas.com.br/dePeso/16,MI299108,71043-

A+saga+jurisprudencial+do+dano+moral+coletivo+tinha+razao+o+saudoso. Acesso em 06.11.2019.

MARINONI, Luiz Guilherme. "Formação da Convicção e Inversão do Ônus da Prova Segundo as Peculiaridades do Caso Concreto". Argumenta Journal Law. Jacarezinho, n.5, 2005.

http://seer.uenp.edu.br/index.php/argumenta/article/view/42 Acesso em 12.01.2020.

; ARENHART, Sérgio Cruz. Prova e Convicção de acordo com o CPC de 2015. 3. ․ Ed. São Paulo: Revista dos Tribunais, 2015.

. Tutela Inibitória e Tutela de Remoção do llícito. 7. a ed. São Paulo: Revista dos Tribunais, 2019.

. "O Direito Ambiental e As Ações Inibitória e de Remoção do llícito". [s.d]. Disponível em: http://www.marinoni.adv.br/wp-content/uploads/2012/06/PROFMARINONI-O-DIREITO-AMBIENTAL-E-AS-AÇÕES-INIBITÓRIA-E-DEREMOÇÃO-DO-ILÍCITO.pdf. Acesso em: 11.01.2020.

MARMELSTEIN, Carlos. Curso de Direitos Fundamentais. São Paulo: Atlas, 2018.

MARSHALL, Thomas Humphrey. Cidadania, classe social e status. Trad. de Meton Porto Gadelha. Rio de Janeiro: Zahar, 1967.

MARTINS, Leonardo. Liberdade e Estado Constitucional: leitura jurídico-dogmática 
de uma complexa relação a partir da teoria liberal dos direitos fundamentais. São Paulo: Atlas, 2012.

Tribunal Constitucional Federal Alemão: decisões anotadas sobre direitos fundamentais. São Paulo: Konrad-Adenauer-Stiftung-KAS, v. 1, 2016.

Tribunal Constitucional Federal Alemão: decisões anotadas sobre direitos fundamentais. São Paulo: Konrad-Adenauer-Stiftung-KAS, v. 2, 2018.

MARTINS-COSTA, Judith. "A ilicitude derivada do exercício contraditório de um direito: o renascer do 'venire contra factum proprium'". Revista da AJURIS. Porto Alegre, v. 32, n. 97, jan./mar. 2005.

; PARGENDLER, Mariana Souza. "Usos e Abusos da Função Punitiva (punitive damages e o Direito Brasileiro)". Revista Centro de Estudos Judiciários. Brasília, v. 9, n. 28, jan./mar. 2005.

MATTOS, Caio. "Democracia é insubstituível e melhor regime para 42 países, diz estudo". Veja "on line", 13.12.2019.

Disponível em: https://veja.abril.com.br/mundo/democracia-e-insubstituivel-e-melhor-regimepara-42-paises-diz-estudo/. Acesso em: 15.12.2019.

MAURER, Hartmut. Staatsrecht I. 6. ․ ed. München: C.H. Beck, 2010.

MAYER, Matthias. Untermaß, Übermaß und Wesensgehaltgarantie: Die Bedeutung staatlicher Schutzpflichten für den Gestaltungsspielraum des Gesetzesgebers im Grundrechtsbereich. Baden-Baden: Nomos, 2005.

MAZZILLI, Hugo Nigro. A Defesa dos Interesses Difusos em Juízo: meio ambiente, consumidor, patrimônio cultural e outros interesses. 22.. ed. São Paulo: Saraiva, 2009.

MEDEIROS, Fernanda Luiza Fontoura. Meio Ambiente - direito e dever fundamental. Porto Alegre: Livraria do Advogado, 2004.

MEIRELLES, Hely Lopes. "Proteção Ambiental e Ação Civil Pública". Revista de Direito Administrativo. Rio de Janeiro, v. 165, jul./set. 1986. Disponível em: http://bibliotecadigital.fgv.br/ojs/index.php/rda/article/view/45164. Acesso em: 30.10.2019.

MELO, Melissa Ely. Restauração Ambiental: do dever jurídico às técnicas reparatórias. Porto Alegre: Livraria do Advogado, 2012.

MENDES, Conrado Hübner. O Projeto de uma Corte Deliberativa. In: VOJVODIC, Adriana; PINTO, Henrique Motta; GORZONI, Paula et al (org.). Jurisdição Constitucional no Brasil. São Paulo: Malheiros, 2012.

MENDES, Gilmar Ferreira. "Os Limites da Revisão Constitucional". Revista dos Tribunais Online, pub. orig. em Revista de Direito Constitucional e Internacional. São Paulo: Revista dos Tribunais, v. 21, out./dez.1997 (paginação da versão eletrônica difere da versão impressa). Disponível em: www.rtonline.com.br. Acesso em: 26.11.2019.

; BRANCO, Paulo Gustavo Gonet. Curso de Direito Constitucional, 6. ${ }^{a}$ ed., São Paulo: Saraiva, 2011.

; STRECK, Lenio Luiz. Comentários ao art. 102, § 1.․, in: CANOTILHO, J. J. Gomes; MENDES, Gilmar Ferreira; SARLET, Ingo Wolfgang et. al. 
Comentários à Constituição do Brasil. 2. ed. São Paulo: Saraiva Educação, 2018 (Série IDP).

. Estado de Direito e Jurisdição Constitucional. 2. ${ }^{\text {a }}$ ed. São Paulo: Saraiva Educação, 2018 (Série IDP).

MENDES, João Múcio Amado. "A Responsabilidade Civil do Proprietário de Área Contaminada: algumas reflexões sobre a lei de áreas contaminadas do Estado de São Paulo (Lei 13.577/2009)", in: Benjamin, Antonio H. et al. (org.) Anais do 17. ${ }^{\circ}$ Congresso Brasileiro e 7.. Congresso de Estudantes de Direito Ambiental. São Paulo: Instituto o Direito por um Planeta Verde, v. 2, 2012.

MESQUITA, Manuel Henrique. Obrigações Reais e Ônus Reais. Coimbra: Almedina, 2003.

MICHAEL, Lothar. "As três estruturas de argumentação do princípio da proporcionalidade - para a dogmática da proibição de excesso e de insuficiência e dos princípios da igualdade", in: HECK, Luís Afonso (org.). Direito Natural, Direito Positivo, Direito Discursivo. Trad. HECK, Luís Afonso. Porto Alegre: Livraria do Advogado, 2010.

"Verhältnismäßigkeit als Schlüssel(bund)konzept", in: JESTAEDT, Matthias; LEPSIUS, Oliver (Hrsg.). Verhältnismäßigkeit: zur Tragfähigkeit eines verfassungsrechtlichen Schlüsselkonzepts. Tübingen: Mohr Siebeck, 2015.

MILARÉ, Édis. Direito do Ambiente. São Paulo: Revista dos Tribunais, 2015.

MIRANDA, Francisco Cavalcanti Pontes de. Tratado de Direito Privado: Parte Especial - Direito das Coisas. Direitos Reais Limitados. Enfiteuse. Servidões. 3. ${ }^{a}$ ed. Rio de Janeiro: Borsoi, t. XVIII. 1971.

MIRANDA, Jorge; MEDEIROS, Rui. Constituição Portuguesa Anotada. Coimbra: Coimbra, t. I, 2005. . Manual de Direito Constitucional. Coimbra: Coimbra, t. 4, 2015. Direitos Fundamentais. 2. ${ }^{\text {a }}$ ed. Coimbra: Almedina, 2017.

MIRANDA, Marcos Paulo de Souza. Tutela do Patrimônio Cultural Brasileiro: doutrina - jurisprudência - legislação. Belo Horizonte: Del Rey, 2006.

MIRRA, Álvaro Luiz Valery. Ação civil pública e a reparação do dano ao meio ambiente. São Paulo: Juarez de Oliveira, 2002.

MOLLO, Marcelo; JOHL, Alyssa; WAGNER, J. Martin et al. Environmental Human Rights Report: Human Rights and the Environment - Materials for the 61st Session of the United Nations Comission on Human Rights. Geneva, March 14 - April 22, 2005. Oakland, California: Earthjustice Legal Defense Fund, 2005, n. 172; Disponível em: http://earthjustice.org/sites/default/files/library/references/2005_ENVIRONME NTAL_RIGHTS_REPORTrev.pdf. Acesso em: 29.05.2018.

MORAES, Alexandre de. Direitos Humanos Fundamentais. 8. ed. São Paulo: Atlas, 2007.

MORAES, Maria Celina Bodin de. Danos à Pessoa Humana: uma leitura civilconstitucional dos danos morais. 2. ${ }^{a}$ ed. Rio de Janeiro: Processo, 2017. 
MÖSTL, Markus. Die Staatliche Garantie für die öffentliche Sicherheit und Ordnung. Tübingen, Mohr Siebeck, 2002.

MUKAI, Toshio. Direito Ambiental Sistematizado. 5. ${ }^{\mathrm{a}}$ ed. Rio de Janeiro: Forense Universitária.

MURSWIEK, Dietrich. Die staatliche Verantwortung für die Risiken der Technik. Berlin: Duncker und Humblot, 1985.

NABAIS, José Casalta. O Dever Fundamental de Pagar Impostos: contributo para a compreensão constitucional do estado fiscal contemporâneo. Coimbra: Almedina, 2004.

NASCIMENTO, Filippe Augusto dos Santos. Direitos Fundamentais e sua Dimensão Objetiva. Porto Alegre: Sérgio Antonio Fabris, 2016.

NERY JÚNIOR, Nelson; NERY, Rosa Maria B. B. de Andrade. "Responsabilidade Civil, Meio-Ambiente e Ação Coletiva Ambiental", in: BENJAMIN, Antonio Herman V. (coord.). Dano ambiental: Prevenção, Reparação e Repressão. São Paulo: Revista dos Tribunais, v. 2, 1993.

. "Responsabilidade Civil por Dano Ecológico e a Ação Civil Pública", in: MILARÉ, Édis; MACHADO, Paulo Affonso Leme (org.). Dano ambiental: responsabilidade em matéria ambiental. (Coleção doutrinas essenciais, Direito Ambiental, v. 5). São Paulo: Revista dos Tribunais, 2011.

; NERY, Rosa Maria de Andrade. Código Civil Comentado. São Paulo: Revista dos Tribunais, 2019.

NEVES, Marcelo. Entre Hidra e Hércules: princípios e regras constitucionais como diferença paradoxal do sistema jurídico. 3. ㄹ ed. São Paulo: Martins Fontes, 2019.

NIPPERDEY, Itans Carl. "Grundrechte und Privatrecht", in: Festschrift für Erich Molitor zum 75. Geburtstag. München: C. H. Beck, 1962.

NORONHA, Fernando. Direito das Obrigações. 4. ${ }^{a}$ ed. São Paulo: Saraiva, 2003. Formato e-Pub.

"O Nexo de Causalidade na Responsabilidade Civil", in: NERY JÚNIOR, Nelson; NERY, Rosa Maria de Andrade (orgs.). Responsabilidade Civil. (Coleção doutrinas essenciais, Responsabilidade Civil, v. 1). São Paulo: Revista dos Tribunais, 2010.

NOVAIS, Jorge Reis. As Restrições aos Direitos Fundamentais não Expressamente Autorizadas pela Constituição. Coimbra: Coimbra, 2003. 2006 .

Direitos Fundamentais: trunfos contra a maioria. Coimbra: Coimbra,

Direitos Sociais: teoria jurídica dos direitos sociais enquanto direitos fundamentais, 2. . ed. Coimbra: AAFDL Editora, 2017.

Direitos Fundamentais nas Relações entre Particulares: do dever de proteção à proibição do défice. Coimbra: Almedina, 2018.

. Direitos Fundamentais e Justiça Constitucional. Coimbra: AAFDL, 2019.

. Princípios Estruturantes do Estado de Direito. Coimbra: Almedina, 2019. 
NUNES, Anelise Coelho. A Titularidade dos Direitos Fundamentais na Constituição Federal de 1988. Porto Alegre: Livraria do Advogado, 2007.

NUNES JÚNIOR, Vidal Serrano. A Cidadania Social na Constituição de 1988 Estratégias de Positivação e Exigibilidade Judicial dos Direitos Sociais. São Paulo: Verbatim, 2009.

OLIVEIRA, William Figueiredo. Dano Moral Ambiental. Rio de Janeiro: Lumen Juris, 2007.

PACCAGNELLA, Luis Henrique Paccagnella. "Função socioambiental da propriedade rural e Áreas de Preservação Permanente e Reserva Florestal Legal". Revista de Direito Ambiental. São Paulo: Revista dos Tribunais, n. 8, 1997.

PADILHA, Norma Sueli. Fundamentos Constitucionais do Direito Ambiental Brasileiro. Rio de Janeiro: Elsevier, 2010.

PASCUAL, Gabriel Doménech. Derechos Fundamentales y Riesgos Tecnológicos: el derecho del ciudadano a ser protegido por los poderes públicos. Madrid: Centro de Estudios Políticos y Constitucionales, 2006.

PASQUALOTTO, Adalberto. "Responsabilidade Civil por Dano Ambiental: Considerações de Ordem Material e Processual", in: BENJAMIN, Antonio Herman V. (coord.). Dano ambiental: Prevenção, Reparação e Repressão. São Paulo: Revista dos Tribunais, v. 2, 1993.

PENDERGRASS, John. "Direito Ambiental nos Estados Unidos da América". Revista de Direito Ambiental. São Paulo: Revista dos Tribunais, v. 1, jan./mar.1996

PERALES, Carlos de Miguel. La Responsabilidad Civil por Daños al Medio Ambiente. 2. ${ }^{\mathrm{a}}$ ed. Madrid: Civitas, 1997.

PEREIRA, Caio Mário da Silva. Responsabilidade Civil. 12. ${ }^{a}$ ed. Atual. por Gustavo Tepedino. Rio de Janeiro, Forense, 2018.

PEREIRA, Jane Reis Gonçalves. Interpretação Constitucional e Direitos Fundamentais. 2. ${ }^{\text {e }}$ ed. São Paulo: Saraiva, 2018.

PEREIRA, Vinícius. "Brasileiros estão entre os mais céticos com política na região, diz estudo". Folha de São Paulo "on line", 05.04.2016. Disponível em: https://www1 folha.uol.com.br/poder/2016/04/1757330-brasileiros-estao-entreos-mais-ceticos-com-politica-na-regiao-diz-estudo-shtml. Acesso em: 08.12.2019.

PÉREZ LUÑO, Antonio Enrique. Derechos Humanos, Estado de Derecho y Constitución. 5. a ed. Madri: Tecnos, 1995.

. "Kant y los derechos humanos", in: MARTíNEZ, Gregorio Peces-Barba; GARCÍA, Eusebio Fernández; ROIG, Rafael de Asís (dir.) História de los derechos fundamentales. Madrid: Dykinson, t. 2, v. 2, 2009.

. "Las generaciones de derechos humanos". Revista Direitos Emergentes na Sociedade Global. [Universidade Federal de Santa Maria].[s.I.:s.e.], v. 2, n. 1 , jan./jun., 2013, Disponível em: 
https://periodicos.ufsm.br/REDESG/article/view/10183/pdf_1\#.WwwsuExFzLM Acesso em: 28.05.2018.

. Los Derechos Fundamentales. Madrid: Editorial Tecnos, 2013; [s.l.]: Kobo

Editions, 2016. Formato e-Pub.

PETTIT, Philip. A Theory of Freedom: from the psicology to the Politics of Agency.

Cambridge: Polity Press, 2001. Formato Kindle,

PIEROTH, Bodo; SCHLINK, Bernhard. Grundrechte - Staatsrecht II. 28. ${ }^{\underline{a}}$ ed.

Heidelberg-München-Landsberg-Frechen-Hamburg: C.F. Muller, 2012.

PINHO, Hortência Gomes. Prevenção e Reparação de Danos Ambientais: as medidas de reposição natural, compensatórias e preventivas e a indenização pecuniária. Rio de Janeiro: GZ; Stuttgart, Alemanha: R. Bosch, 2010.

PINTO, Paulo Mota. O Direito no Livre Desenvolvimento da Personalidade. Portugal-Brasil Ano 2000. Coimbra: Coimbra, 1999.

PIOVESAN, Flávia. Direitos Humanos e o Direito Constitucional Internacional. 12. ed. São Paulo: Saraiva, 2011.

PIVA, Rui Carvalho. Bem Ambiental. São Paulo: Max Limonad, 2000.

POORTER, Jurgen de; BALLIN, Ernst Hirsch; LAVRIJSSEN, Saskia. Judicial Review of Administrative Discretion in the Administrative State. Heidelberg: T.M.C. Asser Press, 2019. Formato Kindle.

PORTO, Mário Moacyr. "Pluralidade de causas do dano e redução da indenização - Força maior e dano ao ambiente", in: MILARÉ, Édis; MACHADO, Paulo Affonso Leme (org.). Dano ambiental: responsabilidade em matéria ambiental. (Coleção doutrinas essenciais, Direito Ambiental, v. 5). São Paulo: Revista dos Tribunais, 2011.

POPPER, Karl R. A Lógica da Pesquisa Científica. trad. HEGENBERG, Leonidas; MOTA, Octanny Silveira da. 2. ㄹ ed. São Paulo: Cultrix, 2013.

POSCHER, Ralf. Grundrechte als Abwehrrechte. Tübingen: Mohr Siebeck, 2003.

PRIGOGINE, llya. O Fim das Certezas: tempo, caos e as leis da natureza. 2. ${ }^{\mathrm{a}}$ ed. São Paulo: UNESP, 2011.

PUGA, Mariela. "La Litis Estructural em el Caso Brown v. Board of Education", in: ARENHART, Sérgio Cruz; JOBIM, Marco Félix (orgs.). Processos Estruturais. 2. ${ }^{a}$ ed. Salvador: Juspodivm.

PULIDO, Carlos Bernal. Principio de Proporcionalidad y los Derechos Fundamentales: el principio de proporcionalidade como criterio para determinar el contenido de los derechos fundamentales vinculante para el legislador. 4. ed. Bogotá: Universidad Externado de Colombia, 2014. Formato e-Pub.

RAMOS, André de Carvalho. Teoria Geral dos Direitos Humanos na Ordem Internacional. 6. ${ }^{a}$ ed. São Paulo: Saraiva, 2016.

Curso de Direitos Humanos. 5.. ed. São Paulo: Saraiva Educação, 2018. Formato Kindle.

RASSOW, Reinhard. "Zur Konkretisierung des Untermaßverbotes". Zeitschrift für Gesetzgebung. Heidelberg: Müller, n. 20, 2005. 
Staatliche Schutzpflichten für geistiges Eigentum (Verfassungsrecht in Forschung und Praxis). Hamburg: Dr. Kovac, 2006.

REALE, Miguel. Filosofia do Direito. 20. ed. São Paulo: Saraiva, 2002.

REHBINDER, Eckard. "Ziele, Grundsätze, Strategien und Instrumente", in: REHBINDER, Eckard; SCHINK, Alexander (Hrsg.). Grundzüge des Umweltrechts. 5. ${ }^{\mathrm{a}}$ ed. Berlin: Erick Schmidt, 2018.

ROBBERS, Gerhard. Sicherheit als Menschenrecht: Aspekte der Geschichte, Begründung und Wirkung einer Grundrechtsfunktion. Baden-Baden: Nomos, 1997.

RODOTÀ, Stefano. II Terribile Diritto - studi sulla proprietà privata e i beni comuni. 3. ${ }^{a}$ ed. Bologna: II Mulino, 2013.

RODRIGUES, Luis Fernando Matricardi. A Proibição de Insuficiência e o STF: há controle de proporcionalidade da omissão estatal? São Paulo: Sociedade Brasileira de Direito Público, 2009. Disponível em: http://www.sbdp.org.br/arquivos/monografia/158_MLF.pdf. Acesso em 05.01.2018.

RODRIGUES, Marcelo Abelha. Instituições de Direito Ambiental. São Paulo: Max Limonad, v. 1, 2002.

ROMANO, Santi. Principii di Diritto Costituzionale Generale. 2.. ed. riv. Milano: A. Giuffrè, 1946.

ROSENVALD, Nelson. As Funções da Responsabilidade Civil: a reparação e a

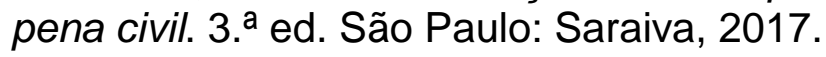

ROBNAGEL, Alexander. Grundrechte und Kernkraftwerke. Heidelberg:[s.e.], 1979.

ROTHENBURG, Walter Claudius. "Princípio da Proporcionalidade", in: OLIVEIRA NETO; Olavo de; LOPES, M. E. de Castro (orgs.). Princípios Processuais Civis na Constituição. São Paulo: Elsevier, 2008.

RUFFERT, Matthias. Vorrang der Verfasssung und Eigenständigkeit des Privatrechts - Eine vefassungsrechtliche Untersuchung zur Privatrechtswirkung des Grundgesetzes. Tübingen: Mohr Siebeck, 2001.

SACHS, Michael. "Einfuhrung", in: SACHS, Michael (Hrsg). Grundgesetz Kommentar. 3. ㄹ ed. München: C.H. Beck, 2003.

SALGE JUNIOR, Durval. Instituição do Bem Ambiental no Brasil, pela Constituição Federal de 1988: seus reflexos jurídicos ante os bens da União. São Paulo: Juarez de Oliveira, 2003.

SALLES, Carlos Alberto de. Execução Judicial em Matéria Ambiental. São Paulo: Revista dos Tribunais, 1999.

"Propriedade imobiliária e obrigações propter rem pela recuperação ambiental do solo degradado". Revista dos Tribunais Online, pub. orig. in: Revista de Direito Ambiental, São Paulo, Revista dos Tribunais, n. 34, abr./jun., 2004 (paginação da versão eletrônica difere da versão impressa). Disponível em: www.rtonline.com.br. Acesso em 15.10.2019. 
SAMPAIO, Francisco José Marques. Responsabilidade Civil e Reparação de Danos ao Meio Ambiente. 2. ${ }^{a}$ ed. Rio de Janeiro: Lumen Juris, 1998.

Evolução da Responsabilidade Civil e Reparação de Danos Ambientais. Rio de Janeiro: Renovar, 2003.

SAMPAIO, Jorge Silva. O Dever de Protecção Policial de Direitos, Liberdades e Garantias. Coimbra: Coimbra, 2012.

SANDEL, Michael J. Justiça - O que é fazer a coisa certa. 4. ${ }^{a}$ ed. Trad. Heloisa Matias e Maria Alice Máximo. Rio de Janeiro: Civilização Brasileira, 2011.

SANDS, Philippe; PEEL, Jacqueline. Principles of International Environmental Law. 4. ${ }^{\mathrm{a}}$ ed. Cambridge, U.K: Cambridge University Press, 2008. Formato Kindle,

SANTOS, Boaventura de Sousa. Por uma concepção multicultural de direitos humanos. In: Revista Crítica de Ciências Sociais, n. 48. Coimbra: Faculdade de Economia da Universidade de Coimbra/Centro de Estudos Sociais, jun/1997. Disponível em: http://www.boaventuradesousasantos.pt/media/pdfs/Concepcao_multicultural_ direitos_humanos_RCCS48.PDF. Acesso em: 30.06.2018.

SANTOS, Cláudia Maria Cruz; DIAS, José Eduardo de Oliveira Figueiredo; ARAGÃO, Maria Alexandra de Sousa, in: CANOTILHO, José Joaquim Gomes Canotilho (coord. cient.). Introdução ao Direito do Ambiente. Lisboa: Universidade Aberta, 1998.

SARLET, Ingo Wolfang. "Direitos fundamentais e Direito Privado: algumas considerações em torno da vinculação dos particulares aos direitos fundamentais", in: SARLET, Ingo Wolfgang (org.), A Constituição Concretizada. Porto Alegre: Livraria do Advogado, 2000.

"A Dimensão Objetiva dos Direitos Fundamentais", in: SAMPAIO, José A. Leite. Jurisdição Constitucional e Direitos Fundamentais. Belo Horizonte: Del Rey, 2003.

. "Constituição, proporcionalidade e direitos fundamentais: o direito penal entre proibição de excesso e de insuficiência". Boletim da Faculdade de Direito de Coimbra, vol. 81, 2005.

"Proibição de retrocesso, dignidade da pessoa humana e direitos sociais: manifestação de um constitucionalismo dirigente possível", in: BONAVIDES, P.; Lima, F. G. M. de; BEDÊ, F. S. (orgs.). Constituição e Democracia: estudos em homenagem ao Prof. J. J. Gomes Canotilho. São Paulo: Malheiros, 2006.

. Dignidade (da Pessoa) Humana e Direitos Fundamentais na Constituição Federal de 1988. 10. ㄹ ed. Porto Alegre: Livraria do Advogado, 2015.

; FENSTERSEIFER, Tiago. Princípios do Direito Ambiental. 2. ${ }^{a}$ ed. São Paulo: Saraiva, 2017.

A Eficácia dos Direitos Fundamentais. 13. ㄹ ed. Porto Alegre: Livraria do Advogado, 2018.

; BRANDÃO, Rodrigo. Comentários ao art. 60, in: CANOTILHO, J. J. Gomes; MENDES, Gilmar Ferreira; SARLET, Ingo Wolfgang et. al. Comentários 
à Constituição do Brasil. 2. ${ }^{a}$ ed. São Paulo: Saraiva Educação, 2018 (Série IDP).

; FENSTERSEIFER, Tiago. Direito Constitucional Ecológico. 6. ${ }^{a}$ ed. São Paulo: Revista dos Tribunais, 2019.

SARMENTO, Daniel. Direitos Fundamentais e Relações Privadas. Rio de Janeiro: Lumen Juris, 2004.

SCAFF, Fernando Campos; LEMOS, Patrícia Faga Iglecias. "Da Culpa ao Risco na Responsabilidade Civil", in: RODRIGUES JÚNIOR, Otávio Luiz; MAMEDE, Gladston; ROCHA, Maria Vital (Coord.), Responsabilidade Civil Contemporânea: em homenagem a Sílvio de Salvo Venosa. São Paulo: Atlas, 2011.

SCHERZBERG, Arno. Grundrechtsschutz und "Eingriffsintensität": Das Ausmass individueller Grundrechtsbetroffenheit als materiellrechtliche und kompetenzielle Determinante der verfassungsgerichtlichen Kontrolle der Fachgerichtsbarkeit im Rahmen der Urteilsverfassungsbeschwerde. Berlin: Duncker \& Humblot, 1989.

. "Wertkonflikte vor dem Bundesverfassungsgericht - zur Bewältigung politisch-moralischer Streitfragen im Verfassungsrecht". Deutsches Verwaltungsblatt. Köln-Berlin-Bonn-München: Carl Heymanns Verlag, 1999.

SCHLAICH, Klaus. Das Bundesverfassungsgericht: Stellung, Verfahren, Entscheidungen. München: C.H. Beck, 1985.

SCHMIDT-JORTZIG, E. "Grundrechte und Liberalismus", in: MERTEN, Detlef; PAPIER, Hans-Jürgen ( $\mathrm{Hg}$.). Handbuch der Grundrechte in Deutschland und Europa. Heidelberg: C. F. Müller, v.1, 2004.

SCHREIBER, Anderson. Direito Civil e Constituição. São Paulo: Atlas, 2013.

Novos Paradigmas da Responsabilidade Civil: da erosão dos filtros da reparação à diluição dos danos. 6. ${ }^{a}$ ed. São Paulo: Atlas, 2015.

SCHULTZE-FIELITZ, Helmuth, In: DREIER, Horst (Hrsg.) Grundgesetz

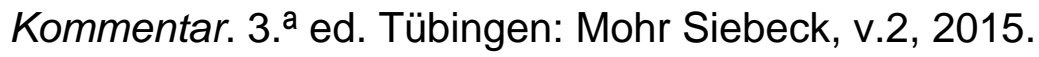

SCHUPPERT, Gunnar Folke. Funktionell-rechtliche Grenzen der Verfassungsinterpretation, Königstein: Athenäum, 1980.

"Die Verfassungsgerichtsbarkeit im Gefüge der Staatsfunktionen". Besteuerung und Eigentum: Berichte und Diskussionen auf der Tagung der Vereinigung der Deutschen Staatsrechtslehrer zu Innsbruck vom 1. bis 4. Oktober 1980 (pp. i-ii). "Veröffentlichungen der Vereinigung der Deutschen Staatsrechts/ehrer". Berlin-New York: de Gruyter, 1981. Formato pdf.

SCHWABE, Jürgen. Die Sogenannte Drittwirkung der Grundrechte. München: Goldmann, 1971.

. "Bundesverfassungsgericht und ,Drittwirkung" der Grundrechte". Archiv des öffentlichen Rechts. [s.l.]: Mohr Siebeck, 100, n. 3, 1975. Disponível em: www.jstor.org/stable/44305602. Acesso em: 28.03.2019.

. Probleme der Grundrechtsdogmatik. Darmstadt: s. e., 1977. 
SCHWETZEL, Wolfram. Freiheit, Sicherheit, Terror: Das Verhältnis von Freiheit nach dem 11. September 2001 auf verfassungsrechtlicher und einfachgesetzlicher Ebene. München: Vahlen, 2007.

SEEWALD, Otfried. Zum Verfassungsrecht auf Gesundheit. Köln-Berlin-BonnMünchen: Carl Heymanns, 1981.

SHAPIRO, Ian. The State of Democratic Theory. Princeton-Woodstock: Princeton University Press, 2003. Formato Kindle.

SIECKMANN, Legal Reasoning: the methods of balancing. Stuttgart: Steiner, 2010.

SILVA, Jorge Pereira da. Deveres do Estado de Protecção dos Direitos Fundamentais. Lisboa: Universidade Católica, 2015.

SILVA, José Afonso da. "Fundamentos Constitucionais da Proteção do Meio Ambiente". Revista de Direito Ambiental. São Paulo: Revista dos Tribunais, jul./set., n. 27, 2002.

. Direito Ambiental Constitucional. São Paulo: Malheiros, 2007.

. Curso de Direito Constitucional Positivo. 33.. ed. São Paulo: Malheiros, 2010.

Comentário Contextual à Constituição. 9. a ed. São Paulo: Malheiros, 2014. STAUT JÚNIOR, Sebastião Vilela. "Apontamentos sobre a Responsabilidade Civil do Poder Público enquanto Réu em Ação Civil Pública de Natureza Ambiental". Revista de Direitos Difusos. São Paulo: IBAP, APRODAB, v. 36, mar./abr. 2006.

SILVA, Virgílio Afonso da. "Prinzipientheorie, Abwägungskompetenzen und Gewaltenteilung", in: SIECKMANN, Jan-R. (Hrsg.). Die Prinzipientheorie der Grundrechte: Studien zur Grundrechtstheorie Robert Alexys. Baden-Baden: Nomos, 2007.

."Interpretação Constitucional e Sincretismo Metodológico", in: SILVA, Virgílio Afonso da (org.). Interpretação Constitucional. São Paulo: Malheiros, 2008.

Direitos fundamentais: conteúdo essencial, restrições e eficácia. São Paulo: Malheiros, 2010.

SZCZEKALLA, Peter. Die sogenannten Schutzpflichten im deutschen und europäischen Recht. Berlin: Duncker und Humblot, 2002.

SOARES, Guido Fernando Silva. Direito Internacional do Meio Ambiente. São Paulo: Atlas, 2001.

. A Proteção Internacional do Meio Ambiente. Barueri: Manole, 2003.

SOARES-FILHO, Britaldo Silveira. Impacto da Revisão do Código Florestal: como viabilizar o grande desafio adiante? SAE; UFMG, [s.d]. Disponível em: https://www.socioambiental.org/sites/blog.socioambiental.org/files/nsa/arquivo s/artigo-codigo-florestal_britaldo_soares_sae_2013pdf.pdf. Acesso em: 13.01.2020.

SOUZA NETO, Cláudio Pereira de; SARMENTO, Daniel. Direito Constitucional: teoria, história e métodos de trabalho. 2.. ed. Belo Horizonte: Fórum, 2019. 
STAECHLIN, Gregor. "Läßt sich das 'Unrtemaßverbot' mit einem liberalen Strafrechtskonzept vereinbaren?", in: Institut für Kriminalwissenschaften Frankfurt a M. (Hrsg.). Vom unmöglichen Zustand des Strafrechts. Frankfurt am Main - Berlin - Bern: Peter Lang, v. 50, 1995.

STARCK, Christian. "Der verfassungsrechtliche Schutz des ungeborenen menschlichen Lebens: Zum zweiten Abtreibungsurteil des BVerfG". JuristenZeitung. [s.l.]: Mohr Siebeck, n. 17, set., 1993.

STEIGLEDER, Annelise Monteiro. "Aspectos jurídicos da reparação de áreas contaminadas por resíduos industriais". Revista dos Tribunais Online, pub. orig. in: Revista de Direito Ambiental. São Paulo: Revista dos Tribunais, n. 29, jan./mar., 2003 (paginação da versão eletrônica difere da versão impressa). Disponível em: www.rtonline.com.br. Acesso em 15.10.2019.

. Responsabilidade Civil Ambiental: as dimensões do dano ambiental no direito brasileiro. 2. ${ }^{\mathrm{a}}$ ed. Porto Alegre: Livraria do Advogado, 2011.

STERN, Klaus. Das Staatsrecht der Bundesrepublik Deutschland: Allgemeine Lehren der Grundrechte. München: C.H. Beck, v. III/1, 1988.

STOCCO, Rui. Tratado de Responsabilidade Civil: doutrina e jurisprudência. 10. ed. São Paulo: Revista dos Tribunais, 2014.

STÖRRING, Lars Peter. Das Untermaßverbot in der Diskussion: Untersuchung einer umstrittenen Rechtsfigur. Berlin: Duncker und Humblot, 2009.

STRECK, Lenio Luiz. "Bem Jurídico e Constituição: da Proibição de Excesso (Übermaßverbot) à Proibição da Proteção Deficiente (Untermaßverbot) ou de como não há blindagem contra normas penais inconstitucionais". Boletim da Faculdade de Direito de Coimbra, v. 80, 2004. . Jurisdição Constitucional. 6. ${ }^{\text {a }}$ ed. Rio de Janeiro: Forense, 2019.

TAVARES, André Ramos. Curso de Direito Constitucional. 16. ${ }^{a}$ ed. São Paulo: Saraiva, 2018.

TEIXEIRA NETO, Felipe. Dano Moral Coletivo: a configuração e a reparação do dano extrapatrimonial por lesão aos interesses difusos. Curitiba: Juruá, 2014.

THEODORO JÚNIOR, Humberto. Curso de Direito Processual Civil: teoria geral do direito processual civil e processo de conhecimento. Rio de Janeiro: Forense, v. 1, 2011.

THIBIERGE, Catherine. "Libre propôs sur l'évolution du droit de la responsabilité (vers um élargissement de la fonction de la responsabilité civile?". Revue trimestrielle de droit civil. Paris: Dalloz, n.3 jul./set. 1999.

TRINDADE, Antonio Augusto Cançado. "Derechos de solidariedad", in: ARANGUREN et al., Estudios Básicos de Derechos Humanos. San José (Costa Rica): $\quad I I D H, \quad$ t. $1,1994 . \quad$ Disponível em: http://www.iidh.ed.cr/IIDH/media/2250/estudios-basicos-01-1994.pdf. Acesso em: 12.06.2018.

TUNC, André. La Responsabilité Civile. Paris: Economica, 1981.

TZEMOS, Vasileios. Das Untermaßverbot. Frankfurt am Main: Peter Lang, 2004. 
UNGER, Russel. "Brandishing the Precautionary Principle through the Alien Tort Claims Act", in: MILARÉ, Édis; MACHADO, Paulo Affonso Leme (org.). Dano ambiental: responsabilidade em matéria ambiental. (Coleção doutrinas essenciais, Direito Ambiental, v. 5). São Paulo: Revista dos Tribunais, 2011.

UNRUH, Peter. Zur Dogmatik der grundrechtlichen Schutzpflichten. Berlin: Duncker \& Humblot, 1989.

VAN DER BROOCKE, Alexandre Moreira. Direitos Fundamentais e Proibição da Proteção Suficiente (Untermaßverbot). Curitiba: CRV, 2016.

VENOSA, Sílvio de Salvo. Direito Civil- Obrigações e Responsabilidade Civil. 19. a ed. São Paulo: Atlas, v. 2, 2019.

VESTENA, Carolina Alves. Participação ou Formalismo? O Impacto das Audiências Públicas no Supremo Tribunal Federal Brasileiro. Dissertação de Mestrado. Rio de janeiro: Escola de Direito, Fundação Getúlio Vargas, 2010. Disponível em: https://bibliotecadigital.fgv.br/dspace/handle/10438/7832. Acesso em 29.12.2019.

VIEIRA, Oscar Viena. "A Constituição como Reserva de Justiça". Lua Nova: Revista de Cultura e Política [on line]. N. 42, 1997. Disponível em: http://www.scielo.br/pdf/ln/n42/a03n42.pdf. Acesso em: 25.11.2019.

WAHL, Rainer; MASING, Johannes. "Schutz Durch Eingriff". JuristenZeitung. [s.I.]: Mohr Siebeck, v. 45, n. 12, 1990. Disponível em: www.jstor.org/stable/20821522. Acesso em: 25.08.2019.

WANDT, Andrew P. H. Die Begrenzung der Aktionärsrechte der öffentlichen Hand. Berlin: Duncker und Humblot, 2005.

WEDY, Gabriel. O princípio constitucional da precaução como instrumento de tutela do meio ambiente e da saúde pública. 2. ${ }^{a}$ ed. Belo Horizonte: Editora Fórum, 2017.

; MOREIRA, Rafael Martins Costa. Manual de Direito Ambiental: de acordo com a jurisprudência dos tribunais superiores. Belo Horizonte: Fórum, 2019.

WEISS, Carlos. Direitos Humanos Contemporâneos. São Paulo: Malheiros, 2006.

WEISS, Edith Brown. In Fairness to Future Generations: International Law, Common Patrimony, and Intergenerational Equity. Tokyo: The United Nations University; New York: Transnational Publishers, 1992.

WOLKMER, Antonio Carlos. "Introdução aos fundamentos de uma teoria geral dos 'novos' direitos". Revista Jurídica. Curitiba: Unicuritiba, vol. 2, n. 31, 2013. Disponível

em: http://revista.unicuritiba.edu.br/index.php/RevJur/article/view/593/454. Acesso em: 30.05.2018.

YOKOHAMA, Alessandro Otavio. Teoria da Proporcionalidade: o judiciário como legislador. Curitiba: Juruá, 2018

ZAGREBELSKI, Gustavo; MARCENÒ, Valeria. Giustizia Costituzionale II: Oggetti, procedimenti, decisioni. 2. ed. Bologna: II Mulino, 2018. 
ZWERMANN-MILSTEIN, Nina Tabea. Grund und Grenzen einer verfassungsrechtlich gebotenen gesundheitlichen Mindestversorgung. BadenBaden: Nomos, 2015. 